\title{
Indigenous Peoples and the Jurisgenerative Moment in Human Rights
}

\author{
Kristen A. Carpenter* \\ Angela R. Riley**
}

As indigenous peoples have become actively engaged in the human rights movement around the world, the sphere of international law, once deployed as a tool of imperial power and conquest, has begun to change shape. Increasingly, international human rights law serves as a basis for indigenous peoples' claims against states and even influences indigenous groups' internal processes of decolonization and revitalization. Empowered by a growing body of human rights instruments, some as embryonic as the 2007 United Nations Declaration on the Rights of Indigenous Peoples (UNDRIP), indigenous peoples are embracing a global "human rights culture" to articulate rights ranging from individual freedom and equality to collective self-determination, property, and culture. Accordingly, this Essay identifies and provides an account of what we see as an unprecedented, but decidedly observable, phenomenon: the current state of indigenous peoples' rights-manifesting in tribal, national, and international legal systems-reflects the convergence of a set of dynamic, mutually reinforcing conditions. The intersection of the rise of international human rights with paradigm shifts in postcolonial theory has, we argue, triggered a "jurisgenerative moment" in

Copyright (C) 2014 California Law Review, Inc. California Law Review, Inc. (CLR) is a California nonprofit corporation. CLR and the authors are solely responsible for the content of their publications.

* Associate Dean for Faculty Development, Associate Professor, and Director of the American Indian Law Program, University of Colorado Law School.

** Professor of Law, UCLA School of Law; Director, UCLA American Indian Studies Center. With thanks to Harvard Law School, the University of Colorado Law School, and Michigan State University Law School for opportunities to present this article. We would also like to thank the Colorado Law School and UCLA School of Law for supporting this research. We also wish to thank the many colleagues who have shaped our thinking on these issues at these and other engagements, including Robert T. Anderson, S. James Anaya, Asli Bali, Bethany Berger, William Boyd, John Borrows, Richard Collins, Jennifer Denetdale, Jorge Esquirol, Matthew L.M. Fletcher, Carole Goldberg, Kim Gottschalk, Lorie Graham, Aya Gruber, Lani Guinier, Lakshman Guruswamy, Terri Henry, Sarah Krakoff, Kal Raustiala, Russell Robinson, Alex Skibine, Wenona T. Singel, Joseph William Singer, Gerald Torres, Charles Wilkinson, and Robert A. Williams, Jr. We would also like to thank Will Haney for his outstanding research assistance. 
indigenous rights. Bringing indigenous norms and values to their advocacy, indigenous peoples have worked to assert their voices in, and indeed to influence, the human rights movement. Indigenous peoples are now using the laws and language of human rights, shaped by indigenous experiences, not only to engage states but also as a tool of internal reform in tribal governance. This is, in our view, a jurisgenerative moment in indigenous rights-a moment when both the concept and practice of human rights have the potential to become more capacious and reflect the ways that individuals and peoples around the globe live, and want to live, today.

Introduction

I. Antecedents to the Jurisgenerative Moment

A. Formation: Rights of Indigenous Peoples

1. The Colonial Period

2. The Emergence of International Human Rights Law

3. Evolutions in International Law and the Increasing

Recognition of the Human Rights of Indigenous Peoples ..... 189

B. Indigenous Peoples and Human Rights Law: Some Critiques......... 192

1. Skepticism About International Human Rights ........................ 193

2. The Myths and Consequences of Cultural Cohesion ................ 195

II. Nomos, Narrative, and the Decolonization of Human Rights Law...... 198

A. Robert Cover and the Nomos and Narrative of American Indian

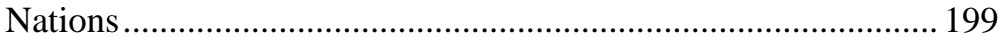

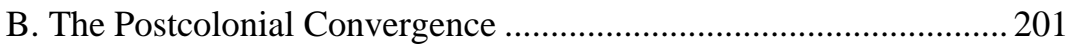

1. American Indian Tribes and the United States ......................... 201

2. The Decolonization Literature .................................................... 204

III. Indigenous Peoples and the Jurisgenerative Moment in Human

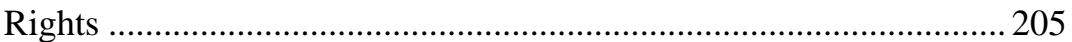

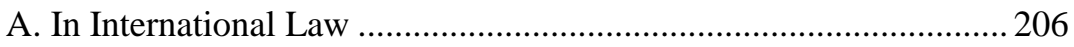

B. In Domestic Legal Systems .......................................................... 211

C. Human Rights in Indigenous Legal Systems .................................... 216

1. A Brief Survey of Indigenous Engagement with International Human Rights Law: International and Indigenous Norms

2. The Recovery and Revitalization of Indigenous Human

Rights in Two Communities: The Navajo Nation and

Eastern Band of Cherokee Indians

a. The Navajo Nation Human Rights Commission: Race

Relations, Sacred Sites, and Water Rights 222

b. The Eastern Band of Cherokee Indians: Responding to Violence Against Women ................................................ 226 


\section{INTRODUCTION}

As indigenous peoples ${ }^{1}$ have become actively engaged in the human rights movement around the world, the sphere of international law, once deployed as a tool of imperial power and conquest, ${ }^{2}$ has begun to change shape. International human rights law now serves as a basis for indigenous peoples' claims against states and even influences indigenous groups' internal processes of revitalization. Empowered by a growing body of human rights instruments, some as embryonic as the 2007 United Nations Declaration on the Rights of Indigenous Peoples (UNDRIP), ${ }^{3}$ indigenous peoples are increasingly recognized in international human rights law as possessing the "right to have rights." ${ }^{4}$ From a historic rights vacuum, indigenous peoples have emerged to embrace the evolution of a global "human rights culture" 5 and to articulate rights ranging from individual freedom and equality to collective selfdetermination, property, and culture. ${ }^{6}$

An examination of these global, if nascent, shifts in indigenous rights reveals a dynamic and complex system that stretches well beyond international legal regimes and into state and indigenous forums alike. This "multiple site"7

1. For our working definition, we follow S. James Anaya who identifies "indigenous peoples" as those who

are indigenous because their ancestral roots are embedded in the lands in which they live, or would like to live, much more deeply than the roots of more powerful sectors of society living on the same lands or in close proximity.... [T]hey are peoples to the extent they comprise distinct communities with a continuity of existence and identity that links them to the communities, tribes, or nations of their ancestral past.

S. JAMES ANAYA, INDIGENOUS PEOPLES IN INTERNATIONAL LAW 3 (2d ed. 2004).

2. See InT'L LAW Ass'N, Hague ConferenCE, Rights of INDigenous PEOPLES 1 (2010) ("Traditional international law, Eurocentric in origin, has worked to largely ratify the attempts at the cultural, if not physical, eclipse of indigenous peoples."). See generally ANTONY ANGHIE, IMPERIALISM, SOVEREIGNTY AND THE MAKING OF INTERNATIONAL LAW (2005).

3. G.A. Res. 61/295, ๆ 12, U.N. Doc. A/RES/61/295 (Sept. 13, 2007) [hereinafter UNDRIP]; see also WALteR R. ECHO-HAWK, IN THE LIGHT OF JuSTICE: THE RISE OF HUMAN RightS IN NATIVE AMERICA AND THE UN DECLARATION ON THE RIgHTS OF INDIGENOUS PEOPLES 3 (2013) (describing the UNDRIP as "a landmark event that promises to shape humanity in the post-colonial age").

4. See HANNAH ARENDT, THE ORIgins OF TOTALITARIANISM 296 (1951).

5. See Helen Stacy, Relational Sovereignty, 55 STAN. L. REV. 2029, 2049 (2003).

6. Following Louis Henkin, we define "human rights" as the "moral-political claims which, by contemporary consensus, every human being has or is deemed to have upon his society and government.” Louis Henkin, Rights: American and Human, 79 ColUM. L. REV. 405, 405 (1979). Examples include the rights enumerated in international instruments, including the UNDRIP, and increasingly accepted as embodied in the International Covenant on Civil and Political Rights, G.A. Res. 2200, 21 U.N. GAOR, Supp. (No. 16) at 52, U.N. Doc. A/6316 (1967), and the International Covenant on Economic, Social and Cultural Rights, G.A. Res. 2200, 21 U.N. GAOR, Supp. (No. 16) at 49, U.N. Doc A/6316 (1967). For leading analysis categorizing indigenous peoples' human rights vis-à-vis categories of international law, see, e.g., Lorie M. Graham \& Siegfried Wiessner, Indigenous Sovereignty, Culture, and International Human Rights Law, 110 S. ATLANTIC Q. 403, 405 (2011) (analyzing the recognition of provisions of the UNDRIP as customary international law).

7. Judith Resnik, Law's Migration: American Exceptionalism, Silent Dialogues, and Federalism's Multiple Ports of Entry, 115 YALE L. J. 1564, 1670 (2006). 
engagement has produced a profound human rights moment, one manifested in the development of interrelated and inter-reliant legal norms and structures.

Events comprising the indigenous rights movement reveal not only "law's migration," "8 but also its generative force and potential to loosen colonization's bind. In 2001, for example, the Inter-American Court on Human Rights held that Nicaragua's obligation to protect property rights under Article 21 of the American Convention on Human Rights encompassed interests defined by the Awas Tingni peoples' own customary law of land tenure. ${ }^{9}$ In 2006, Navajo Indians created a tribal human rights commission and later successfully lobbied for the recognition of water and subsistence rights against powerfully aligned federal, tribal, and corporate interests. ${ }^{10}$ In 2007, the highest court of Belize ruled in favor of indigenous property rights, based on customary land tenure, citing heavily to the then-draft of the Declaration on the Rights of Indigenous Peoples. ${ }^{11}$ Later that year, indigenous groups-having gathered for twenty years at the United Nations in Geneva to press for international studies, hearings, and lawmaking on indigenous rights-witnessed the General Assembly adopt the Declaration on the Rights of Indigenous Peoples by a vote of 144 to $4 .^{12}$ Within three years, the most ardent dissenters, Canada, New Zealand, Australia, and the United States, all reversed their opposition and adopted the Declaration.

These examples reflect only a few of the seismic shifts occurring in indigenous rights. For decades, indigenous peoples from across the globe have relied on human rights regimes to challenge the laws of the nation-states in which they reside. ${ }^{13}$ They have articulated their claims, pursuant to treaties and other instruments, before the Inter-American Commission and Court on Human Rights as well as before the U.N. Human Rights Council. ${ }^{14}$ Their claims often invoke indigenous legal norms that have increasingly received recognition in individual cases and have begun to influence the development of international human rights law itself. ${ }^{15}$ Concurrently, nation-states are beginning to accept

8. See generally id.

9. Mayagna (Sumo) Awas Tingni Cmty. v. Nicaragua, Inter-Am. Ct. H.R. (ser. C) No. 79 (2001), available at http://www1.umn.edu/humanrts/iachr/AwasTingnicase.html.

10. See Mission/Vision, NAVAJO NATION HuMAN RightS COMMission, http://www.nnhrc .navajo-nsn.gov/mission_vision.html (last visited Nov. 7, 2013) [hereinafter NNHRC Mission/Vision].

11. Aurelio Cal v. Belize, Supreme Court of Belize (Claims No. 171 and 172 of 2007) (Oct. 18, 2007), available at http://www.elaw.org/node/1620.

12. See UNDRIP, supra note 3, $\mathbb{1} 12$.

13. See S. James Anaya, Indian Givers: What Indigenous Peoples Have Contributed to International Human Rights Law, 22 WASH. U. J.L. \& POL’Y 107, 108 (2006).

14. See infra Part III.

15. See, e.g., Dann v. United States, Case 11.140, Inter-Am. Comm'n H.R., Report No. 75/02, OEA/Ser.L./V/II.117, doc. 5 rev. I 5 (2002), available at http://www1.umn.edu/humanrts/cases/75 -02a.html ("[T]he Commission concluded that the State has failed to ensure the Danns' right to property under conditions of equality contrary to Articles II, XVIII and XXIII of the American Declaration in connection with their claims to property rights in the Western Shoshone ancestral lands.”). 
human rights norms derived from international and indigenous sources in their own judicial decisions, constitutions, and other activities. ${ }^{16}$ And indigenous peoples themselves are employing human rights discourse as a tool for internal reflection and reform. ${ }^{17}$ These phenomena are inextricably intertwined in substance and form, ultimately reinforcing and reifying a truly indigenous body of human rights law.

Building on our previous work, ${ }^{18}$ this Essay sets out to document and provide a theoretical account of an unprecedented, but decidedly observable, phenomenon: the current state of indigenous peoples' rights-manifesting at the tribal, national, and international levels - reflects the convergence of a set of dynamic, mutually reinforcing conditions. The intersection of the rise of international human rights, increased indigenous participation in legal development, and paradigm shifts in postcolonial theory has triggered a truly indigenous human rights movement, one that pervades lawmaking at multiple levels. This is, we assert, a realization of Robert Cover's vision in Nomos and Narrative: ${ }^{19}$ paideic communities that live their commitments and absorb, process, and create law "all the way down." ${ }^{20}$ Just as profoundly, we argue, indigenous peoples are influencing law around and outside of their communities, all the way up into state and international practice. By participating in the human rights movement as peoples, indigenous peoples have begun to transcend the state-centric model that often excludes other groups meriting legal and political attention on the world stage. ${ }^{21}$ In

16. See infra Part III.

17. See infra Part III.

18. See, e.g., THE INDIAN CIVIL RIGHTS ACT AT FORTY (Kristen A. Carpenter, Matthew L.M. Fletcher \& Angela R. Riley eds., 2012); Kristen A. Carpenter, A Property Rights Approach to Sacred Sites Cases: Asserting a Place for Indians as Nonowners, 52 UCLA L. REV. 1061 (2005) [hereinafter Carpenter, Sacred Sites]; Kristen A. Carpenter, Sonia K. Katyal \& Angela R. Riley, In Defense of Property, 118 YALE L.J. 1022 (2009) [hereinafter Carpenter et al., In Defense]; Angela R. Riley, Good (Native) Governance, 107 CoLUM. L. REV. 1049 (2007) [hereinafter Riley, Governance]; Angela R. Riley, (Tribal) Sovereignty and Illiberalism, 95 CALIF. L. REV. 799 (2007) [hereinafter Riley, Illiberalism].

19. Robert M. Cover, The Supreme Court, 1982 Term-Foreword: Nomos and Narrative, 97 HARV. L. REV. 4, 11 (1983).

20. See Mark V. Tushnet, Following the Rules Laid Down: A Critique of Interpretivism and Neutral Principles, 96 HARV. L. REV. 781, 792 n.32 (1983).

21. Our previous works consider some of the bases for treating indigenous groups as “peoples.” See Carpenter et al., In Defense, supra note 18, at 1051-57; Kristen A. Carpenter, Real Property and Peoplehood, 27 STAN. ENVTL. L.J. 313, 346-57 (2008); Riley, Governance, supra note 18, at 1123. For a helpful account of indigenous peoples' involvement in international law as challenging the state-centric model, see Lillian Aponte Miranda, Indigenous Peoples as International Lawmakers, 32 U. PA. J. INT'L L. 203 (2010). For seminal works on the rights and responsibilities of “peoples” more generally, compare JOHN RAWLS, THE LAW OF PEOPLES 25, 79-81 (1999) (proposing categories of "peoples" that should be recognized as playing a role in the international legal order and articulating limits on the behavior of non-liberal peoples such that they may still retain their autonomy), with MARTHA C. NuSSBAUM, FrontiERS OF JUSTICE: DisABILITIES, NATIONALITY, SPECIES MEMBERSHIP 244, 263 (2006) (critiquing Rawls's concept of “peoples” as vague and arguing for a more robust view of human rights). See also Lakshman Guruswamy, Energy Justice and 
"uncovering" their own legal traditions and working to "decolonize"22 indigenous experiences, ${ }^{23}$ they increasingly expect international human rights law to reflect and advance indigenous norms - and for indigenous law, in turn, to reflect the best of international human rights principles. They are advocating this nuanced approach to human rights in various forums, including tribal, state, and international tribunals, as well as legislatures, agencies, and other organs of civil society. In short, we argue, the world is witnessing a jurisgenerative moment in indigenous peoples' human rights. ${ }^{24}$ Finally, in setting forth the case for the jurisgenerative moment, we also seek in this work to encourage greater dialogue across the fields of indigenous rights and international human rights. Indigenous rights scholarship is uniquely concerned with the role of indigenous peoples in the human rights movement and whether international law will affect indigenous peoples in their real-life struggles. ${ }^{25}$ Although international

Sustainable Development, 212 COLO. J. INT’L \& ENVTL L. \& POL’Y 231, 258-65 (2010) (highlighting Rawls's discussion regarding the duty of liberal democratic peoples to assist “burdened societies”).

22. See, e.g., Robert B. Porter, A Proposal to the Hanodaganyas to Decolonize Federal Indian Control Law, 31 U. Mich. J.L. Reform 899, 904 (1998); Robert B. Porter, Building a New Longhouse: The Case For Government Reform Within the Six Nations of the Haudenosaunee, 46 BUFF. L. REV. 805, 934 (1998) (advocating decolonization of Native nations); Robert A. Williams, Jr., The Algebra of Federal Indian Law: The Hard Trail of Decolonizing and Americanizing the White Man's Indian Jurisprudence, 1986 WIS. L. REV. 219, 220-26 (1986) (discussing federal Indian law as colonial and a vision for reformation); see also MisHUANA GOEMAN, MARK MY WORDS: NATIVE WOMEN MAPPING OUR NATIONS 32-39 (2013) (describing the process of colonization as “ongoing”); Daniel Heath Justice, “Go Away, Water!”: Kinship Criticism and the Decolonization Imperative, in REAsoning Together: The NATIVE Critics Collective 147 (Craig S. Womack el al. eds., 2008) (discussing Native American Studies literature on decolonization).

23. Compare JOHN BORROWS, RECOVERING CANADA: THE RESURGENCE OF INDIGENOUS LAW, at xii (2002) (arguing that "the power of Aboriginal law can still be discerned despite the pervasiveness of imported law”), and JOHN BORROWS, CANADA's INDIGENOUS CONSTITUTION 2355 (2010) (describing sources and categories of indigenous law including sacred, natural, deliberative, positivistic, and customary), with RAYMOND D. AUSTIN, NAVAJO COURTS AND NAVAJO COMMON LAW: A TRADITION OF TRIBAL SELF-GOVERNANCE, at xvii (2009) (describing “a unique side to tribal court jurisprudence in the United States ... [that] involves retrieving ancient tribal values, customs, and norms and using them to solve contemporary legal issues.”).

24. Our use of the phrase "jurisgenerative moment" draws on both the work of Robert Cover with respect to the jurisgenerative nature of certain lawmaking communities, and that of Bruce Ackerman, who adroitly coined the "constitutional moment." Cover, supra note 19; Bruce Ackerman, A Generation of Betrayal?, 65 FORDHAM L. REV. 1519, 1519 (1997) (explaining that “[a] constitutional moment occurs when a rising political movement succeeds in placing a new problematic at the center of American political life”). We are not the first to draw on Cover's work to identify other “jurisgenerative moments." See Judith Resnik, Living Their Legal Commitments: Paideic Communities, Courts, and Robert Cover, 17 YALE J. L. \& HUM. 17, 27 (2005).

25. See, e.g., JAMES (SA'KE'J) YOUNGBLOOD HENDERSON, INDIGENOUS DiPLOMACY AND THE RIGHTS OF PEOPLES: ACHIEVING UN RECOGNITION (2008) (providing an indigenous legal history account of the international human rights movement); MAKING THE DECLARATION WORK: THE UNiTED NATIONS DECLARATION ON THE RightS OF INDIGENOUS PEOPLES (Claire Charters \& Rudolfo Stavenhagen eds., 2009) (offering reflections and analysis by indigenous, state, and international representatives who participated in the processes of conceiving, negotiating, adopting, and implementing the UNDRIP) [hereinafter MAKING THE DECLARATION WORK]; REFLECTIONS ON THE UN DECLARATION ON THE RIgHTS OF INDIGENOUS PEOPLES (Stephen Allen \& Alexandra Xanthaki eds., 2011) [hereinafter REFLECTIONS ON UNDRIP]. 
human rights scholarship has considered questions surrounding the development $^{26}$ and implementation ${ }^{27}$ of international human rights law, such consideration has usually been in other contexts. Even more specifically, to the extent that human rights discourse addresses the norm of self-determination ${ }^{28}$ or the role of non-state actors in international law, ${ }^{29}$ it could benefit from deeper engagement with indigenous peoples’ experiences. ${ }^{30}$

26. See, e.g., MARY ANN GLENDON, A WORLD MADE NEW: ELEANOR ROOSEVELT AND THE UNIVERSAL DECLARATION OF HUMAN RIGHTS (2001) (situating the human rights movement in the values and structures emerging after World War II); LYNN HUNT, INVENTING HUMAN RIGHTS: A HISTORY (2007) (tracing the human rights movement to Enlightenment thinking and articulations of rights in the French and American Revolutions); SAMUEL MOYN, THE LAST UtOPIA: HUMAN RIGHTS IN HISTORY (2010) (arguing that the contemporary human rights movement emerged as a "utopian" movement after the demise of other political platforms in the 1970s).

27. See, e.g., Ryan Goodman \& Derek Jinks, How to Influence States: Socialization and International Human Rights Law, 54 DuKE L.J. 621 (2004) (arguing that international human rights law wields influence through coercion, persuasion, and acculturation); Oona A. Hathaway, Between Power and Principle: An Integrated Theory of International Law, 72 U. CHI. L. REV. 469 (2005) (arguing that international treaties wield influence by rule of law regimes within state parties and through collateral consequences of treaty membership, including foreign aid, investment, aid, and politics).

28. See Goodman \& Jinks, supra note 27, at 653 (“[C]ounterhegemonic norms exhibit the same pattern of diffusion as prohegemonic norms, suggesting that conventional conceptions of global power politics provide an inadequate descriptive account. One important example is the norm of selfdetermination (understood as a fundamental human right), which supported decolonization and motivated many indigenous rights campaigns.”). For more on the topic of indigenous peoples and selfdetermination, see generally ANAYA, supra note 1, at 97-184 (elaborating on the norm of selfdetermination in international law as it pertains to indigenous peoples); see also CHARLES WILKINSON, BLOOD STRUGGLE: THE RISE OF MODERN INDIAN NATIONS (2006) (describing the selfdetermination movement in the United States); Stephen Cornell \& Joseph P. Kalt, Self-Determination: The Political Economy of a Policy that Works (Harvard Univ. HKS Faculty Research Working Paper Series, Paper No. RWP10-043, 2010), available at http://dash.harvard.edu/handle/1/4553307.

29. See, e.g., Harold Hongju Koh, Remarks: Twenty-First-Century International Lawmaking, 101 GEO. L.J. 725, 743 (2013) ("Finally, the new twenty-first-century international lawyering process recognizes that states are not the only actors. Of course, neither international law nor foreign policy have ever been completely restricted to states, but the proliferation and influence of nonstate actors has 'gone viral' in recent years. And so it is inevitable that the United States government now finds itself developing relationships not just with states, but with civil-society and industry groups too, among others.") (internal citations omitted); see also ANDREW CLAPHAM, HUMAN RIGHTS OBLIGATIONS OF NONSTATE ACTORS 2 (2006); Philip Alston, The 'Not-a-Cat' Syndrome: Can the International Human Rights Regime Accommodate Non-State Actors?, in NON-STATE ACTORS AND HuMAN RigHTS 3, 3-5 (Philip Alston ed., 2005). With respect to indigenous peoples as nonstate actors, see, for example, Clare Boronow, Note, Closing the Accountability Gap for Indian Tribes: Balancing the Right to SelfDetermination with the Right to a Remedy, 98 VA. L. REV. 1373, 1410-16 (2012) (suggesting indigenous peoples may have rights and obligations under international human rights law through their relationship with states, a more capacious approach to international legal personality, and/or because they are persons or entities who enjoy certain rights and duties as a matter of customary international law); Robert J. Miller, Inter-Tribal and International Treaties for American Indian Economic Development, 12 LEWIS \& CLARK L. REV. 1103, 1118-19 (2008) (considering whether Indian tribes might be bound by the General Agreement on Tariffs and Trade, the North American Free Trade Agreement, or the World Trade Organization).

30. See Ryan Goodman \& DereK Jinks, Socializing States: Promoting Human RIGHTS THOUGH INTERNATIONAL LAW 60-86 (2013) (analyzing the results of empirical studies in the areas of constitutional design, children's rights, female suffrage, and domestic violence). We recognize 
Our Essay proceeds as follows: In Part I, we consider the development of the international human rights movement, particularly as a response to conquest and colonization by states, and also highlight some of the key critiques to the movement. Part II lays the theoretical background for this work, situating it within international law, postcolonial indigenous theory, and Robert Cover's work on the jurisgenerative process in paideic communities. Finally, Part III gives life to the jurisgenerative moment by providing a snapshot of the multiple ways in which we see human rights developing in indigenous, national, and international settings around the globe today.

I.

\section{ANTECEDENTS TO THE JURISGENERATIVE MOMENT}

In this part, we consider certain antecedents to the current jurisgenerative moment. Historically, there have been debates about whether international law justifies indigenous conquest or guarantees indigenous rights, including whether international law offers a viable alternative to oppressive domestic legal regimes created to subdue indigenous peoples. In contemporary times, wherein tribal people are increasingly asserting their collective autonomy in governance, culture, and economic matters, many indigenous peoples have coalesced around the use of human rights law as an instrument of decolonization and self-determination. Accordingly, Section A identifies several historical moments when indigenous peoples engaged with international law and legal institutions, focusing on examples that presage the contemporary indigenous human rights movement.

Nonetheless, we do not attempt to provide a comprehensive history of indigenous legal interactions with states around the world, a subject that would clearly exceed the scope of this piece. ${ }^{31}$ Several of our examples come from the United States and Canada, as well as New Zealand and Australia, reflecting particular patterns of settler-colonialism that we describe below. In other parts

the relatively nascent state of the indigenous rights field and acknowledge that it may still be too soon to undertake empirical studies that would most deeply and comprehensively inform these inquiries. At this point, therefore, we offer several preliminary observations, and hope that these will lead to additional scholarly work in the future.

31. For a broad discussion of colonial experiences around the world and the role of indigenous peoples in lawmaking and shaping the international legal order, see generally LAUREN BENTON, LAW AND COlONiAl CUltures: LEgAL REgIMES IN WORLD HiSTORY, 1400-1900 (2002); KeN S. CoAtes, A Global History of Indigenous PeOples: StRugGle AND Survival (2004). For a broad treatment of the history of indigenous peoples around the globe, see generally ANAYA, supra note 1, at 15-72 (providing a historical context for international law's treatment of indigenous peoples from the fifteenth century into the modern era); ROBERT A. WILLIAMS, JR., THE AMERICAN INDIAN IN Western LegAL Thought: The Discourses of Conquest (1990) (tracing the role of Western legal thought in the conquest and colonization of indigenous peoples and lands by Spain, France, England, and the United States from the fifteenth to nineteenth centuries). For an explanation of how and where indigenous and minority rights diverged, see Will Kymlicka, The Internationalization of Minority Rights, 6 INT’L J. CONST. L. 1, 6-31 (2008). 
of the world, including Latin America, ${ }^{32}$ Asia, ${ }^{33}$ Africa, ${ }^{34}$ the Arctic, ${ }^{35}$ Oceania and the Pacific, ${ }^{36}$ and the Middle East, ${ }^{37}$ indigenous peoples often experienced conquest and colonization on different legal grounds that led to similar experiences of widespread impoverishment, dislocation, and loss of culture and religion. Across the world, the concept of "who is indigenous" remains contested and varied, as do contemporary legal problems and strategies. ${ }^{38}$ Acknowledging these limitations and opportunities for further work, we offer the following brief account to provide helpful historical, legal, and thematic touchstones for our jurisgenerative argument.

\section{A. Formation: Rights of Indigenous Peoples}

\section{The Colonial Period}

Colonizers and indigenous peoples initially acted as separate sovereigns, governed by international law. With the arrival of Europeans, indigenous peoples became involved in matters of trade, passage, and security. ${ }^{39}$ In 1493 , Pope Alexander granted Spain and Portugal authority over diplomacy,

32. See, e.g., CHARles Gibson, THE AZTECs UnDER SPANISH RulE: A History OF THE INDIANS OF THE VALLEY OF MEXICO, 1519-1810 (1964); REBECCA HORN, POSTCONQUEST COYOACAN: NAHUA-SPANISH RELATIONS IN CENTRAL MEXICO, 1519-1650 (1997); 3 THE CAMBRIDGE History of Native PEOPles of THE AMERICAS: SOUTH AMERICA (Frank Salomon \& Stuart B. Schwartz eds., 1999); THE INDIAN IN LATIN AMERICAN HISTORY: RACE, RESILIENCE, AND ACCULTURATION (John E. Kicza ed., 2000).

33. See, e.g., THE CONCEPT OF INDIGENOUS PEOPLES OF Asia: A RESOURCE BOOK (Christian Erni ed., 2008); see also InDigenous PEOPLES AND THE STATE: Politics, LAND, AND ETHNICITY IN THE MALAyAn PENInsula AND BoRNEO (Robert L. Winezeler ed., 1997); Benedict Kingsbury, "Indigenous Peoples" in International Law: A Constructivist Approach to the Asian Controversy, 92 AM. J. INT’L L. 414 (1998).

34. See, e.g., ALBERT KWOKWo BARUme, LAND Rights OF INDIGENOUS PEOPLES IN AFRICA (2010); Rachel Murray, The UN Declaration on the Rights of Indigenous Peoples in Africa: The Approach of the Regional Organisations to Indigenous Peoples, in REFLECTIONS ON UNDRIP, supra note 25 , at 485 .

35. See, e.g., CONTESTEd ARCtic: Indigenous Peoples, Industrial STATES, AND tHE CirCUMPOLAR ENVIRONMENT (Eric Alden Smith \& Joan McCarter eds., 1997); MARK NUTTALL, Protecting The Arctic: Indigenous Peoples And Cultural SuRvival (1998); see also Noel

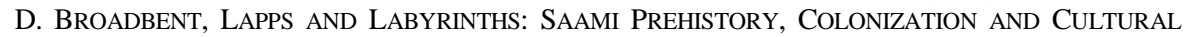
Resilience (2010); Veli PeKKA-Lehtola, The SÁmi People: Traditions in TRANSition (2004).

36. See generally Stuart BANNER, Possessing the Pacific: LAND, SETtlers, AND INDIGENOUS PEOPLES FROM AUSTRALIA TO ALASKA (2007).

37. See, e.g., Jibrail S. JABBUR, THE BEDOUINS AND the DeSERT: AsPeCtS OF NOMADIC LIFE IN THE ARAB EAST (1995); MORDECHAI NISAN, MiNORITIES IN THE MidDLE EAST: A HiSTORY OF STRUGGLE AND SELF-EXPRESSION (2d ed. 2002).

38. For helpful reports on the indigenous peoples in the nation-states of regions around the world, see The Indigenous World, INTERNATIONAL WORK GROUP FOR INDIGENOUS AFFAIRS, http://www.iwgia.org/regions (last visited Nov. 9, 2013).

39. For a popular history account of such encounters, see NATHANIEL PHILBRICK, MAYFLOWER: A STORY OF COURAGE, COMMUNITY, AND WAR 99-113 (2006) (describing the treaty between Puritan Governor William Bradford and Indian leader Massasoit, entered into within months of the Mayflower's arrival at Plymouth). 
governance, and trade with indigenous peoples around the world. ${ }^{40}$ Spanish representatives implemented the encomienda system granting conquistadors, soldiers, and officials dominion over Indian land and labor in the Americas and the Caribbean. ${ }^{41}$ The Dominican cleric Bartolomé de las Casas decried practices including the killing and enslavement of Indians and, along with the theologian Francisco de Vitoria, espoused the concept of "humanity" of indigenous peoples. ${ }^{42}$ Yet while de Vitoria recognized that indigenous peoples had natural rights as free peoples and rejected the pope's broad grant of land title to Spain, he also allowed that indigenous peoples' failure to abide by the law of civilized, Christian nations could justify waging war against them. ${ }^{43}$ Here were some of the seeds of the international law justification for Indian conquest-articulated in the Spanish Requerimiento of 1512-which led to violence, dispossession, and devastation for indigenous peoples. ${ }^{44}$ International law thus provided the European powers with practices and doctrines that both limited and legitimated indigenous conquest and colonization.

In the seventeenth and eighteenth centuries, international law came to be defined as the Law of Nations, which was premised on the natural rights of the nation-state as well as the positive law of treaties and arrangements among states. The Law of Nations projected a certain "ambiguity" with respect to the powers of European states over indigenous peoples, with the Law of Nations' primary intellectual proponent Emmerich de Vattel alternatively citing the right of European states to acquire land pursuant to discovery and decrying the conquest of certain groups. ${ }^{45}$ As a practical reality, during this era, European and indigenous peoples often negotiated the contours of trade, war, and land rights through treaties. Spain recognized limited indigenous governing authority, for example, in negotiating early treaties with indigenous groups in Chile. ${ }^{46}$ Other indigenous peoples signed treaties with England, France, Spain, the Dutch Republic, and other nation-states.

Thus, many of the foundational legal interactions between indigenous peoples and Europeans occurred pursuant to international law, ${ }^{47}$ and sometimes

40. See Robert J. Miller, The International Law of Colonialism: A Comparative Analysis, 15 LEWIS \& CLARK L. REV. 847, 887-88 (2011).

41. See ANAYA, supra note 1 , at 16 .

42. See, e.g., id. at 16-19; KAREN ENGLE, The Elusive Promise OF INDigenOuS DEVELOPMENT: RIGHTS, CULTURE, STRATEGY 19-21 (2010); WILLIAMS, supra note 31, at 95-103.

43. See Robert A. WILliams, JR., THE AMERICAN INDIAN IN WESTERN LEGAL THOUGHT: THE DISCOURSES OF CONQUEST 96-108(1990).

44. See ANAYA, supra note 1, at 16-19, 36 n.20 (quoting King Ferdinand's Requerimiento of 1512 that called on "idolatrous Indians" to acknowledge the supremacy of the Catholic Church, Pope, and Spanish monarchy over them and their lands, or otherwise submit to war, slavery, and the destruction of property).

45. See id. at 20-25.

46. See Miller, supra note 40, at 889-92.

47. See generally Philip P. Frickey, Domesticating Federal Indian Law, 81 MINN. L. REV. 31, 36-38, 52-53 (1996) (tracing this history in the U.S. context and arguing that it provides a basis for 
at the confluence of indigenous and European traditions. ${ }^{48}$ Robert A. Williams, Jr., draws on the example of the Gus-Wen-Tah, or the Two Row Wampum, a treaty made in 1613 between the Haudenosaunee Confederacy and the Dutch to illustrate the encounter and integration of indigenous and European norms in an early legal agreement. ${ }^{49}$ Indeed, indigenous peoples continued to bring their own legal traditions ${ }^{50}$-including concepts of kinship, reciprocity, and sacred trust-to their treaty relationships with Europeans into the eighteenth and nineteenth centuries. ${ }^{51}$

After securing their own freedom from England, however, "settler" states, including the United States, Canada, New Zealand, and Australia, increasingly sought to manage indigenous affairs through state law. ${ }^{52}$ Philip Frickey called this the process of "domesticating" indigenous peoples' law. ${ }^{53}$ In the United States, for example, Indian tribes did not participate in the drafting or ratification of the Constitution; nonetheless, the Constitution gave Congress authority to regulate trade with Indian tribes ${ }^{54}$ and declared treaties to be the "supreme Law of the Land." "55 Shortly thereafter, the U.S. Supreme Court fashioned common law rules both mediating and effectuating conquest. ${ }^{56}$ By virtue of the "Marshall Trilogy" of cases, Indian nations became classified as "dependent domestic sovereigns" that, by virtue of inherent tribal sovereignty,

internationalizing "the way we think about" federal Indian law today, including concepts of sovereignty and plenary power).

48. See generally ROBERT A. WILLIAMS, JR., LINKING ARMS TOGETHER: AMERICAN INDIAN TREATY Visions OF LAW \& PEACE, 1600-1800 (1997).

49. Robert A. Williams, Jr., Sovereignty, Racism, Human Rights: Indian Self-Determination and the Postmodern World Legal System, 2 REV. CONST. STUD. 146, 200-01 (1995).

50. One scholar examines the argument that certain indigenous legal traditions, such as intertribal diplomacy, confederacy-formation, and treaty making should be considered "Indigenous InterNational Laws." See Amar Bhatia, The South of the North: Building on Critical Approaches to International Law with Lessons from the Fourth World, 14 OR. REV. INT'L L. 131, 145-50 (2012).

51. See, e.g., WiLLIAMS, supra note 48 , at 28-39. In one notable instance in 1730 , Cherokee leaders traveled to England to negotiate a treaty with King George, though in many other cases Indians were taken as slaves or specimens, against their will, to serve as labor or curiosities for Europeans. See also Charles F. Wilkinson, To Feel the Summer in the Spring: The Treaty Fishing Rights of the Wisconsin Chippewa, 1991 WIS. L. REV. 375, 384-89 (describing tribal customary law and culture in treaties).

52. For a discussion of "settler colonialism," see Patrick Wolfe, Settler Colonialism and the Elimination of the Native, 8 J. GENOCIDE RES. 387 (2006).

53. Frickey, supra note 47 , at 31.

54. U.S. CONST. art I, § 8, cl. 3 (granting Congress the power "[t]o regulate Commerce with foreign Nations, and among the several States, and with the Indian Tribes") (emphasis added).

55. U.S. CONST. art VI.

56. See Philip P. Frickey, Marshalling Past and Present: Colonialism, Constitutionalism, and Interpretation in Federal Indian Law, 107 HARV. L. REV. 381, 383-85 (1993) (arguing that federal Indian law occupies a contested place between colonialism and constitutionalism that is mediated by doctrines and methodologies of federal Indian common law). 
treaties, and federal supremacy, retained rights of occupancy and selfgovernance over their reserved territories. ${ }^{57}$

Despite these formal rights, tribes were often relocated, sometimes forcibly, from their traditional territories or pressured to accept onerous treaty terms. $^{58}$ In 1871, the U.S. Congress ended new treaty-making with Indian tribes, ${ }^{59}$ and in 1903 the Supreme Court held that the United States could break treaties with tribes without federal court review of such actions pursuant to its "plenary authority" over tribal affairs. ${ }^{60}$ Thus Indian rights were legally protected, but harshly limited, and ultimately subject to the power and politics of the conquering nation. Additional limitations to tribes' criminal and civil jurisdiction would follow. ${ }^{61}$

This was the embodiment of settler colonialism. ${ }^{62}$ In contrast to "[t]raditional colonialism," 63 which relied on a large indigenous population for labor for the benefit of a small group of colonists, ${ }^{64}$ in the settler state, the native society had to be marginalized or eliminated. ${ }^{65}$ In other words, because the colonizers came to stay, "invasion [was] a structure not an event." 66 This version of settler colonialism was replicated with some variation in other nations. In New Zealand, the Treaty of Waitangi of 1840 acknowledged British protection and sovereignty, as well as Maori rights of autonomy over their own affairs. ${ }^{67}$ In Australia, the courts long treated aboriginal lands as terra nullius,

57. See Joseph William Singer, Sovereignty and Property, 86 Nw. U. L. REV. 1, 37-38 (1991). The "Marshall Trilogy" includes Worcester v. Georgia, 31 U.S. 515 (1832); Cherokee Nation v. Georgia, 30 U.S. 1 (1831); and Johnson v. M'Intosh, 21 U.S. 543 (1823). See David H. Getches, Conquering the Cultural Frontier: The New Subjectivism of the Supreme Court in Indian Law, 84 CALIF. L. REV. 1573, 1577 (1996).

58. Shortly after the Supreme Court affirmed the Cherokee Nation's rights over their reserved lands in Worcester v. Georgia, for example, Congress authorized and the executive branch executed the removal of the Cherokee Nation to Indian Territory via the aptly named "Trail of Tears." Thousands of lives were lost and traditional lands were taken. See Rennard Strickland \& William M. Strickland, A Tale of Two Marshalls: Reflections on Indian Law and Policy, the Cherokee Cases, and the Cruel Irony of Supreme Court Victories, 47 OKLA. L. REV. 111, 122-26 (1994).

59. 25 U.S.C. $§ 71$ (1871) (stating that tribes are not entities "with whom the United States may contract by treaty,” although existing treaties are in no way “invalidated or impaired”).

60. Lone Wolf v. Hitchcock, 187 U.S. 553, 565 (1903) (holding that treaty abrogation did not raise justiciable issues that could be reviewed by the Court on the merits).

61. See Oliphant v. Suquamish Indian Tribe, 435 U.S. 191, 212 (1978); see also Montana v. United States, 450 U.S. 544, 566-67 (1981).

62. See PATRICK WOLFE, SETTLER COLONIALISM AND THE TRANSFORMATION OF ANTHROPOlOGY: THE POLITICS AND POETICS OF AN ETHNOGRAPHIC EVENT 1-2 (1999); see also AZIZ RANA, THE TWO FACES OF AMERICAN FREEDOM 8-9 (2010).

63. See Sarah Krakoff, Inextricably Political: Race, Membership, and Tribal Sovereignty, 87 WASH. L. REV. 1041, 1119 (2012).

64. See RANA, supra note 62, at 8.

65. See Wolfe, supra note 52, at 387.

66. Id. at 388 .

67. See MATtheW S.R. PALMER, THE TREATY OF WAitANGI IN NEW ZEALAND'S LAW AND CONSTITUTION (2008). 
freely annexing them for generations. ${ }^{68}$ Canada passed the Indian Act of 1876, "a monolithically injurious piece of legislation" that sought to control and centralize all aspects of Indian life from identity and governance, to land and subsistence. $^{69}$

In all of these nations, and elsewhere around the globe, indigenous peoples were largely denied citizenship rights during the eighteen hundreds and were subjected to laws that distributed their lands, demolished their economies, usurped their traditional governance systems, criminalized their religions, and tried to "assimilate" them into mainstream society. ${ }^{70}$

During periods of intense domination by newly formed nation-states, indigenous peoples continued to pursue international channels for the protection of their rights and brought claims to protest nation-states' assertions of domestic power over them. Indeed, while commentators suggest that historically international law often neglected indigenous subjects per se, it is also apparent that some indigenous peoples believed that the principles of international law applied to them. ${ }^{71}$ Moreover, indigenous peoples presented their claims through advocacy reflecting their own experiences and values, albeit availing themselves of new forums, processes, and languages. ${ }^{72}$

\section{The Emergence of International Human Rights Law}

As soon as an international tribunal became available, indigenous peoples availed themselves of it, and while they were only somewhat successful in initial advocacy, these efforts laid important groundwork for what would become the modern indigenous human rights movement.

One such forum was the League of Nations, formed after World War I, which promised self-determination for states and protection for minorities. ${ }^{73}$ In 1923, the Six Nations (also known as the Iroquois Confederacy) submitted a petition to the League of Nations claiming that Canada was threatening to "destroy all de jure government of the Six Nations" by escalating the presence of the Royal Mounted Police on reserves and other activities designed to

68. See generally BAIN ATTWOOD \& ANDREW MARKUS, THE STRUGGLE FOR ABORIGINAL RigHTS: A DOCUMENTARY HISTORY (1999). This practice was finally reversed by the Australia high court in Mabo v. Queensland (No. 2) (1992) 175 C.L.R. 1, and the Native Title Act 1993 (Cth).

69. See Peter Scott Vicaire, Two Roads Diverged: A Comparative Analysis of Indigenous Rights in a North American Constitutional Context, 58 MCGILL L.J. 607, 636 (2013).

70. See generally Pamela S. Karlan, Lightning in the Hand: Indians and Voting Rights, 120 YALE L.J. 1420 (2011).

71. See, e.g., Ravi de Costa, Identity, Authority, and the Moral Worlds of Indigenous Petitions, 48 COMP. STUD. SOC’Y \& HIST. 669 (2006) (examining petitions_-brought by Aborigines and Islanders of Australia, the Maori of New Zealand, and the First Nations of North America- to the British Empire, the Commonwealth, and the international community from 1846 to 1975).

72. See id. at 675-85.

73. See Antony Anghie, Nationalism, Development and the Postcolonial State: The Legacies of the League of Nations, 41 TEX. INT’L L.J. 447, 448-49 (2006). 
disrupt traditional leadership and governance practices. ${ }^{74}$ The Six Nations claimed the right to be heard, stemming in part from British treaty recognition. ${ }^{75}$ Canada opposed the petition on grounds that " $[\mathrm{t}]$ he Six Nations are not ... a recognized or self-governing people but are ... subjects of the British Crown within the Dominion of Canada."76 The Cayuga traditional leader, Deskaheh, ${ }^{77}$ then personally travelled to Geneva where he won the sympathies of several states, and ultimately received an informal venue to present his claims. $^{78}$

Canada nevertheless kept the Six Nations from addressing the League of Nations - and New Zealand did the same with the Maori; ${ }^{79}$ yet, this early advocacy "set in motion a series of developments that slowly advanced the recognition of indigenous peoples rights in international law." 80 As one commentator notes, these efforts and others were entirely consistent with indigenous traditions of self-government, advocacy, dignity, and respect: "[w]hat was new was the presentation of these credentials to a post-imperial international authority, one assumed to govern a moral world in which there was a dignified place for sovereign indigenous nations." ${ }^{\text {, } 1}$

These efforts, like international law generally, were greatly influenced by post-World War II developments. ${ }^{82}$ The foundational instruments of international human rights law, including the United Nations Charter, Universal Declaration on Human Rights of 1948, and the American Declaration of the Rights and Duties of Man, recognized individual civil and political rights, as well as state interests in self-determination. ${ }^{83}$

But it was not immediately clear that these instruments would promote either the individual or collective interests of indigenous peoples. In 1949, the U.N. General Assembly recommended a study of the condition of "aboriginal populations and other underdeveloped social groups of the American continent" to improve their condition and foster more efficient use of their

74. See S. JAMES ANAya, InTERNATIONAL Human RightS AND INDigENOUS PEOPLES 4-7 (2009).

75. See id. at 6 .

76. See id.

77. See The Encyclopedia of Native American Legal Tradition 84 (Bruce Elliott Johansen ed., 1998) (discussing Deskaheh).

78. ANAYA, supra note 74, at 6-7.

79. See HENDERSON, supra note 25, at 24, 32 (noting that the international awareness brought about by the Maori leader Ratana's 1925 complaints, based on the Treaty of Waitangi, to the League eventually led to land hearings and reform in New Zealand).

80. Wenona T. Singel, New Directions for International Law and Indigenous Peoples, 45 IDAHO L. REV. 509, 510 (2009).

81. De Costa, supra note 71, at 685.

82. See generally Kal Raustiala, Empire and Extraterritoriality in Twentieth Century America, 40 Sw. L. REV. 605 (2011). See also Henkin, supra note 6, at 407-08.

83. See ANAYA, supra note 1, at 251. 
resources. ${ }^{84}$ Several international conferences followed, raising awareness of indigenous peoples. $^{85}$

The first treaty to single out indigenous peoples as special subjects of human rights concern was International Labor Organization Convention (ILO) 107, adopted in $1957 .{ }^{86}$ Concerned about "the exploitation" of indigenous workers during the industrial era, the ILO identified the need to protect "indigenous and other tribal or semi-tribal populations" during the period when they were integrating into larger national societies. ${ }^{87}$ Given this substantive orientation and the lack of participation of indigenous peoples during its drafting, ILO 107 was ultimately viewed as an assimilationist instrument insufficiently cognizant of indigenous interests in political and cultural survival as distinct entities. ${ }^{88}$

In the 1950s and 1960s, some indigenous groups placed great hope in the global decolonization movement, believing that instruments such as the Declaration on the Granting of Independence to Colonial Countries and Peoples (1960)—with its provisions condemning colonialism, segregation, and discrimination-would mean freedom for indigenous peoples as well. ${ }^{89}$ But when colonies in Asia, Africa, and Oceania gained independence, indigenous claims for self-determination and development were merely left to new national governments that did not typically empower indigenous peoples. ${ }^{90}$

As scholars suggest, the failure of the decolonization movement to address indigenous concerns led a new generation of indigenous leaders to focus on human rights instruments as a potential vehicle to address the poverty, land loss, violence, and social problems that often plagued indigenous peoples in the twentieth century. ${ }^{91}$ To the extent that international law addressed minority rights at the time, it was largely without specific attention to indigenous concerns. ${ }^{92}$ The International Covenant on Economic, Social, and Cultural Rights (ICESCR), adopted in 1966, affirmed that all "peoples" have a right to "freely pursue their economic, social and cultural development,"93 and the International Covenant on Civil and Political Rights emphasized the rights

84. G.A. Res. 275 (III), U.N. Doc. A/RES/275 (May 11, 1949).

85. See Russel Lawrence Barsh, Indigenous Peoples: An Emerging Object of International Law, 80 AM. J. INT’L L. 369, 370 (1986).

86. See ANAYA, supra note 1, at 54 .

87. Rebecca Tsosie, Reconceptualizing Tribal Rights: Can Self-Determination Be Actualized Within the U.S. Constitutional Structure?, 15 LEWIS \& CLARK L. REV. 923, 926 (2011).

88. See Alexandra Xanthaki, INDIGENOUS RighTS AND UNITED NATIONS STANDARDS: SELFDETERMINATION, CULTURE AND LAND 49-101 (2007).

89. See, e.g., HENDERSON, supra note 25, at 27-28.

90. Id.

91. See, e.g., id.

92. See generally S. James Anaya, The Capacity of International Law to Advance Ethnic or Nationality Rights Claims, in THE RigHTS OF MinORITY CULTURES 321 (Will Kymlicka ed., 1995).

93. International Covenant on Economic, Social and Cultural Rights art. 1, Dec. 16, 1966, 993 U.N.T.S. 3 (entered into force Jan. 3, 1976) (stating that "[a]ll peoples have the right of selfdetermination”). 
of minority groups "to enjoy their own culture, to profess and practice their own religion, [and] to use their own language." 94 The International Convention on the Elimination of All Forms of Racial Discrimination (CERD) of 1969 required states to adopt measures combating racial prejudices and discrimination, ${ }^{95}$ and certain UNESCO instruments emphasized the right to cultural identity. ${ }^{96}$ Yet, while these international human rights instruments, especially the common recognition of the right to "self-determination" in both the ICCPR and ICESR, offered a potential correction to the Universal Declaration's exclusion of any reference to collective or group rights, states remained eager to quash potential claims for any separate political existence by indigenous groups. ${ }^{97}$ As Rebecca Tsosie points out, states continued to resist indigenous self-determination, "fearing that this might cause political destabilization and trigger movements toward secession."98 In the indigenous rights movement, there were several strands of thinking about selfdetermination, with certain proponents advocating for a robust version of territorial integrity and the right to separate from states; ${ }^{99}$ and others calling for a pragmatic blend of indigenous self-governance and meaningful engagement with states that would not necessarily require secession ${ }^{100}$ to achieve the freedom, integrity, and respect sought by indigenous peoples. ${ }^{101}$

94. International Covenant on Civil and Political Rights art. 27, Dec. 16, 1966, 999 U.N.T.S. 171 (entered into force Mar. 23, 1976) [hereinafter ICCPR].

95. International Convention on the Elimination of All Forms of Racial Discrimination art. 7, Dec. 21, 1965, 660 U.N.T.S. 195 (entered into force Jan. 4, 1969) [hereinafter CERD].

96. See, e.g., U.N. Educ., Sci. \& Cult. Org. (UNESCO), Decl. on Race and Racial Prejudice, UNESCO Gen. Conf. Res. 20 C/Res. 3/1.1/2 art. 5, 20th Sess. (1978), U.N. doc. E/CN.4/Sub.2/1982 /2/Add.1, annex V (1982); Decl. of the Principles of International Cultural Co-operation, UNESCO Gen. Conf. Res. 14 C/Res. 8 art. 1, 14th Sess. (1966).

97. It bears noting, however, that these covenants have resurfaced in more recent years as a source of law available to protect indigenous rights. For example, in Mabo v. Queenland, the court cited Australia's obligations under the International Covenant on Civil and Political Rights. Mabo v. Queensland (No. 2) (1992) 175 C.L.R. 1, 42 (citing the ICCPR). Similarly, the United Nations Human Rights Committee cited to the Covenant's Article 27 in Ominayak v. Canada, Commc'n No. 167/1984, U.N. GAOR, Hum. Rts. Comm., 45th Sess., Supp. No. 40, Annex 9, U.N. Doc. A/45/40 (1990).

98. Rebecca Tsosie, Tribalism, Constitutionalism, and Cultural Pluralism: Where Do Indigenous Peoples Fit Within Civil Society?, 5 U. PA. J. CONST. L. 357, 376 (2003).

99. See generally Patrick Thornberry, Self-Determination and Indigenous Peoples: Objections and Responses, in OPERATIONALIZING THE RIGHT OF INDIGENOUS PEOPLES TO SELFDETERMinATION 39, 52, 54 (Pekka Aikio \& Martin Scheinin eds., 2000).

100. See ANAYA, supra note 1, at 109 (articulating the contours of remedial and ongoing selfdetermination and noting that "[s]ecession... may be an appropriate remedial option in limited contexts . . . where substantive self-determination for a particular group cannot otherwise be assured or where there is a net gain in the overall welfare of all concerned"); see also S. James Anaya, SelfDetermination as a Collective Human Right Under Contemporary International Law, in OPERATIONALIZING THE RIGHT OF INDIGENOUS PEOPLES TO SELF-DETERMINATION, supra note 99, at 3 .

101. Erica-Irene A. Daes, The Spirit and Letter of the Right to Self-Determination of Indigenous Peoples: Reflections on the Making of the United Nations Draft Declaration, in 


\section{Evolutions in International Law and the Increasing Recognition of the}

Human Rights of Indigenous Peoples

By most accounts, it was during this same period, beginning in the 1960s and continuing through the present, that the contemporary indigenous human rights movement gained momentum. ${ }^{102}$ As indigenous peoples around the world gained better access to formal education, economic resources, and political organization, they coalesced around ongoing mistreatment and subordination by states. Indigenous leaders-elders, traditional advisers, organizations, and academics - met at conferences and talking circles. They envisioned the ways in which the ideals of peace, freedom, justice, and membership in the human family captured in the Universal Declaration of Human Rights "were remarkably similar to those [sentiments] embodied in the legal traditions of Indigenous peoples." 103

These developments were accompanied by broader action and involvement around the world. Indigenous advocates began appearing at the ILO, U.N., and UNESCO, and these institutions, in turn, began to reassess the role of indigenous peoples in international law. For example, the International Indian Treaty Council, founded in 1974 at a gathering of the American Indian Movement in Standing Rock, South Dakota, gained "non-governmental organization" status at the U.N. Economic and Social Council in $1977 .{ }^{104}$ The U.N. Sub-Commission on Prevention of Discrimination and Protection of Minorities completed a highly influential study on indigenous peoples, and in 1977 the U.N. hosted a conference of NGOs on discrimination against indigenous peoples, which two hundred indigenous representatives traveled to Geneva to attend. ${ }^{105}$ In 1982, the Sub-Commission on the Promotion and Protection of Human Rights established the Working Group on Indigenous Populations (UNWGIP). The UNWGIP offered a formal structure and venue for indigenous peoples to articulate their values and struggles, and for states to respond. ${ }^{106}$

OPERATIONALIZING THE Right OF InDigENOUS PEOPLES TO SELF-DETERMinATION, supra note 99, at 67,79 .

102. See, e.g., Shelagh LeVangie, Globalized Native Politics: Negotiating the United Nations DeCLARATION on the Rights of Indigenous PeOPles 7 (2008); see also Miranda, supra note 21, at 219 (postulating four factors that have enabled indigenous peoples to participate in international law "during the past forty years," including "(1) shifts in ideological conceptions of indigeneity; (2) local affronts to indigenous peoples' way of life and greater opportunities for transnational coalition-building, simultaneously facilitated by circumstances of globalization; (3) attention under international law to promoting ideals of participatory democracy; and (4) advocacy by indigenous peoples aimed at greater recognition of participatory rights").

103. See HENDERSON, supra note 25, at 31.

104. See INTERNATIONAL INDIAN TREATY COUNCIL, http://www.treatycouncil.org/about.htm (last visited Nov. 10, 2013).

105. See Augusto Willemsen-Diaz, How Indigenous Peoples' Rights Reached the UN, in MAKING THE DECLARATION WORK, supra note 25, at 16, 21.

106. See Robert A. Williams, Jr., Encounters on the Frontiers of International Human Rights Law: Redefining the Terms of Indigenous Peoples' Survival in the World, 1990 DUKE L.J. 660, 672- 
As indigenous peoples developed a growing global consciousness, shared identity, and common set of goals, international human rights instruments began to reflect these sentiments. ${ }^{107}$ In 1989, in response to calls by indigenous peoples and others, the ILO began a process to draft and ultimately adopt a new convention. The resulting instrument, ILO Convention No. 169 "Concerning Indigenous and Tribal Peoples," provided that "indigenous and tribal peoples shall enjoy the full measure of human rights and fundamental freedoms without hindrance of discrimination." ${ }^{108}$ While disclaiming any particular legal effect of the term, ILO 169 recognized the rights of indigenous and tribal "peoples” in a clear departure from ILO 107, and also expressed respect for the ongoing existence of indigenous and tribal lifeways. ${ }^{109}$ More specifically, it acknowledged the "social, cultural, religious, and spiritual values and practices" of indigenous and tribal peoples; called for "special measures" to safeguard the "persons, property, labour, cultures, and environment" of the peoples concerned; and articulated a standard of "due regard" for the "customs and customary law" of indigenous and tribal peoples. ${ }^{110}$ Finally, it provided that state governments "shall ... consult the peoples concerned ... whenever consideration is being given to legislative or administrative measures which may affect them directly." 111

While ILO 169 failed to meet certain aspirations in terms of both process and content, ${ }^{112}$ it was still a relatively progressive instrument for its time. ILO 169 recognized indigenous group identity and community, and called for

82 (1990); see also Erica-Irene A. Daes, The Contribution of the Working Group on Indigenous Populations to the Genesis and Evolution of the UN Declaration on the Rights of Indigenous Peoples, in MAKING THE DECLARATION WORK, supra note 25, at 48.

107. See RoNALD NiEZEN, THE ORIGINS OF INDIGENISM: HuMAN RIGHTS AND THE POLITICS OF IDENTITY 1-28 (2003) (considering the emergence of indigenous identity as a modern phenomenon).

108. International Labour Organisation Convention (No. 169) Concerning Indigenous and Tribal Peoples in Independent Countries art. 3, June 27, 1989 (entered into force, Sept. 5, 1991) [hereinafter ILO Convention No. 169], available at http://www.ilo.org/dyn/normlex/en/f?p= NORMLEXPUB:12100:0::NO::P12100_ILO_CODE:C169; see also ANAYA, supra note 1, at 58-61.

109. ILO Convention No. 169, supra note 108, art. 1(3), arts. 13-44; see also Lee Swepston, The ILO Indigenous and Tribal Peoples Convention (No. 169): Eight Years After Adoption, in HuMAN RightS OF INDigenous PEOPLES, 17, 18-28 (Cynthia Price Cohen ed., 1998).

110. ILO Convention No. 169, supra note 108, arts. 4-5, 8.

111. Id. art 6.

112. The ILO is a tripartite organization in which states are represented by representatives from government, employers, and workers. There is a great deal of literature commenting on the extent to which this structure and adaptations to it allowed indigenous peoples to participate in ILO 169. See, e.g., LUIS RodríGUEZ-PiÑERO, IndigENOUS PEOPles, POSTCOLONIALISM, AND INTERNATIONAL LAW: THE ILO REGIME (1919-1989), at 291-331 (2005) (describing some of the factors that limited indigenous leadership and participation in the ILO 169 drafting and adoption process, thereby challenging the overall legitimacy and legacy of the Convention); Swepston, supra note 109, at 18-28 (describing "special arrangements... made for indigenous representation in order to overcome ... exclusivity in the ILO's concept of NGOs," which included workers' and employers' representatives). 
"special measures" to implement its provisions. ${ }^{113}$ Moreover, as a binding covenant of international law, ILO 169 remains vitally important to indigenous advocacy, especially in Latin America and the Caribbean where fifteen of the twenty states to ratify the Convention are located. ${ }^{114}$

In 1985, the UNWGIP formally embarked on the project of drafting a declaration focused specifically on the rights of indigenous peoples. ${ }^{115}$ The UNWGIP provided opportunities for indigenous peoples to participate in the process, including by commenting on draft principles and working papers. Reflecting these points of engagement, the former chairperson of the Working Group on Indigenous Populations described the "substantive contributions made by indigenous peoples" to the draft declaration. ${ }^{116}$ In 1993, the UNWGIP submitted a draft declaration that was adopted by the Sub-Commission on the Promotion and Protection of Human Rights in 1994. The next year, the Commission on Human Rights considered this draft and established a Working Group on the U.N. Declaration on the Rights of Indigenous Peoples for further work. ${ }^{117}$ States increasingly mobilized to participate in the process. ${ }^{118}$ For years, indigenous and state representatives struggled over the meaning and scope of "indigenous," "peoples," "self-determination," and other key provisions. ${ }^{119}$

The version of the Declaration presented to the General Assembly affirmed that indigenous peoples have the right to full enjoyment, "as a collective or as individuals," of all human rights recognized by the U.N. Charter, Universal Declaration on Human Rights, and international human rights law. ${ }^{120}$ It retained the language from early drafts on "indigenous peoples" and "self-determination," as well as rights to traditional lands, economic development, education, family and child welfare, self-government, culture, religion, expression, and others. ${ }^{121}$ Key provisions call for states to obtain "free, prior and informed consent before adopting and implementing legislative or administrative measures" affecting indigenous peoples. ${ }^{122}$ Near the end of

113. See Tsosie, supra note 87, at 927 ("ILO 169 attempted to create a middle ground, claiming that indigenous peoples were entitled to the full measure of human rights accorded to others, and that their unique social, cultural, religious and spiritual values and practices should be recognized and protected.”).

114. Article 38 of the Statute of the International Court of Justice confirms international treaties, custom, general principles, and judicial decisions as sources of international law. See Statute of the International Court of Justice, June 26, 1945, art. 38, 59 Stat. 1055, 1060.

115. See ANAYA, supra note 1, at 63.

116. See Miranda, supra note 21, at 242 (quoting Erica-Irene Daes).

117. See ANAYA, supra note 1 , at 63.

118. Id. at 63-64.

119. See, e.g., Andrea Carmen, International Indian Treaty Council Report from the Battle Field - The Struggle for the Declaration, in MAKING THE DECLARATION WORK, supra note 25, at 86, 91 (articulating the struggle of indigenous representatives to reflect a broad indigenous viewpoint).

120. UNDRIP, supra note 3, art. 1.

121. Id. arts. $1-46$.

122. Id. art. 19. 
the negotiation process, several African states sought and obtained specific language protecting the territorial integrity of states, a concession that rankled some indigenous representatives. ${ }^{123}$

In 2007, the General Assembly overwhelmingly adopted the Declaration (UNDRIP). ${ }^{124}$ Within several years, the four nations in opposition-the United States, Canada, New Zealand, and Australia_-all reversed their positions. The UNDRIP acknowledges rights common to humanity-such as nondiscrimination, equality, and property - and contexts for the enjoyment of those rights that may appear more particular to indigenous peoples, such as spiritual attachment to traditional lands and a focus on community rights. ${ }^{125}$

As described in greater detail in Part III, ILO 169, UNDRIP, and regional instruments have, in a remarkably short period of time, motivated pivotal changes in laws and values regarding indigenous rights, thereby influencing tribal, domestic, and international legal systems. ${ }^{126}$

\section{B. Indigenous Peoples and Human Rights Law: Some Critiques}

At the same time that the indigenous human rights movement is taking shape, its critics are mobilizing. To provide a richer picture of some of the key tensions in indigenous human rights discourse and advocacy, we outline here the most salient criticisms articulated thus far by scholars and advocates. In doing so, we emphasize the interconnected nature of the critiques and acknowledge that they, like the movement itself, are still emerging. To simplify this discussion, we group the multifaceted critiques in two main lines of thought: skepticism about international human rights law (along several axes) and criticism of the reliance on "culture" (and concomitant claims of homogeneity) to advance indigenous rights.

123. See Charmaine White FACE \& ZUMila Wobaga, Indigenous Nations' RightS IN THE BALANCE: AN ANALYSIS OF THE DECLARATION ON THE RIGHTS OF INDIGENOUS PEOPLE 104-06 (2013) (describing changes made to Article 46 as "offensive").

124. UNDRIP, supra note 3.

125. See generally id. See also HENDERSON, supra note 25, at 11-12 ("Indigenous peoples created the Declaration with their own style of diplomacy with the nation-states and the UN system. This diplomacy is as important as the principles in the Declaration. The tenacity of Indigenous diplomacy and the legal traditions that inform it are the deep structure of the Declaration."); Julian Burger, The UN Declaration on the Rights of Indigenous Peoples: From Advocacy to Implementation, in REFLECTIONS ON UNDRIP, supra note 25, at 41, 42-43 ("[The Declaration] responds to the reallife problems that threaten the existence of indigenous peoples as identified by indigenous peoples themselves. One of the remarkable features of the Working Group ... was that the rights proposed were garnered from specific experiences, expressed in the language of the elder, community leader, woman or youth activist. How else could the recognition of indigenous peoples' spiritual relationship with their lands be included in an international human rights instrument, if not through countless stories of this non-materialist and harmonious bond between humankind and nature?”).

126. It is beyond the scope of this article to elaborate on all international covenants and declarations referencing indigenous peoples. For a helpful source, see generally ANAYA, supra note 1 . 


\section{Skepticism About International Human Rights}

Running through discussions of the drafting and ultimate adoption of the UNDRIP was and is a concern that human rights law generally, ${ }^{127}$ and the UNDRIP in particular, represents the imposition of foreign legal culture on indigenous peoples, with assimilationist overtones and effects. ${ }^{128}$ For one, critics worry that UNDRIP's ultimate implementation holds the unwelcome power to displace tribal cultural values and disrupt tribal relationships, potentially upsetting, for example, gender-specific roles in tribal religions and property distribution systems that may be inapposite to Western notions of individual equality. ${ }^{129}$

Moreover, because the UNDRIP and all international regimes continue to place the nation-state-rather than autonomous, indigenous groups - at their center, indigenous peoples still lack true recognition as political entities. ${ }^{130}$ This potentially undermines rights of self-determination, including the freedom of indigenous groups to "choose their own governments, cultures, and territories from within their own cultural traditions or views." ${ }^{131}$ Essentially, as with past hegemonic regimes, the concern is that indigenous peoples may only guarantee their rights in the international sphere if they do so on the terms of the nationstates and powerful entities that have long worked to dismantle and oppress them. ${ }^{132}$

There is a second strand of skepticism about human rights law surrounding the indigenous rights movement, which represents the other end of the spectrum; that is, whether human rights law is likely to make any difference to indigenous peoples at all. ${ }^{133}$

127. See, e.g., Makau Mutua, Savages, Victims, and Saviors: The Metaphor of Human Rights, 42 HARV. INT'L L.J. 201, 204-06 (2001) (describing human rights as “fundamentally Eurocentric"); Makau Wa Mutua, The Ideology of Human Rights, 36 VA. J. INT’L L. 589 (1996).

128. As Elvira Pulitano writes, "there is indeed a certain irony in the fact that the Declaration is framed in the language of international human rights law, the same law that legitimized the superiority of imperial colonial powers and the destruction of indigenous cultures." See Elvira Pulitano, Introduction to Indigenous Rights IN THE AgE OF THE UN DECLARATION 1, 6 (Elvira Pulitano ed., 2012). H. Patrick Glen also notes the Declaration's roots in "the profoundly western notion of international law." H. Patrick Glenn, The Three Ironies of the UN Declaration on the Rights of Indigenous People, in REFLECTIONS ON UNDRIP, supra note 25, at 171.

129. See Pat Sekaquaptewa, Comments at the Thelton E. Henderson Center for Social Justice Symposium: Heeding Frickey's Call: Doing Justice in Indian Country (Sept. 28, 2012) (describing difficulties in imposing Western notions of equality on tribes wherein religious roles and property rights are assigned by gender).

130. See Duane Champagne, UNDRIP (United Nations Declaration on the Rights of Indigenous Peoples): Human, Civil, and Indigenous Rights, 28 WICAZO SA REv. 9, 20 (2013).

131. Duane Champagne, Indigenous Affirmative Action, INDIAN COUNTRY (Aug. 5, 2011).

132. Id.

133. See, e.g., Duane Champagne, Can UNDRIP Be Enforced?, InDIAN COUNTRY (Mar. 5, 2012). For a nuanced critique along these lines see Miranda, supra note 21, at 204 ("While indigenous peoples' participation may serve to lend greater legitimacy to international human rights law and lawmaking processes, such participation may not effectively deliver material gains.”). International law in general has been sharply criticized by scholars who contend that it rarely works to constrain 
Human rights activists across fields have long operated with a very clear understanding of the sharp limits on change afforded by any international human rights regime. ${ }^{134}$ Pointing to the UNDRIP's status as a nonbinding instrument with no enforcement mechanism, and the lack of domestic implementation in most countries, some suggest that the document is, at best, an aspirational statement of policy with little practical import or effect. ${ }^{135}$ As we describe in greater detail in Part III, even states that have opted in to oversight regimes, such as the ILO's Supervisory System (providing for various types of reports and complaints) or the ICCPR's First Optional Protocol (allowing for complaints to the U.N. Human Rights Committee), may fail to implement the holdings and recommendations of reviewing tribunals. ${ }^{136}$ The possibility of so much weight being placed on UNDRIP when it-and other similar instruments - are incapable of securing real change for indigenous groups bolsters the claim from critics that the indigenous rights movement should direct its energies elsewhere.

Finally, skeptics about international indigenous rights worry that recognition of indigenous rights, especially to property and territory, threatens to reify or rework colonial relationships. In short, there is little guidance in the UNDRIP or otherwise for resolution of competing claims among indigenous groups. Thus, framing claims about traditional land tenure as property rights narrows the focus of indigenous activism to litigation, entrenches disputes among neighboring indigenous groups, and legitimizes the state-centered regimes in which the claims are filed. ${ }^{137}$ When implemented on the ground, moreover, laws that give legal effect to traditional land tenure-but fail to account for the fact that neighboring peoples often have overlapping, multilayered relationships with land and with each other-have arguably led to

state interests, and compliance and enforcement are rare. See, e.g., JACK L. GOLDSMITH \& ERIC A. POSNER, THE LIMITS OF INTERNATIONAL LAW (2005).

134. See generally GOLDSMITH \& POSNER, supra note 133. But see Kal Raustiala, Refining the Limits of International Law, 34 GA. J. INT’L \& COMP. L. 423, 427 (2006) (contending that Goldsmith and Posner's critiques of international law "bend too far towards realist skepticism" and fail to take account of "a wide range of scholarship illustrating the power of international law and institutions"); Laurence R. Helfer \& Anne-Marie Slaughter, Why States Create International Tribunals: A Response to Professors Posner and Yoo, 93 CALIF. L. REV. 899 (2005). See also STONES OF HOPE: HOW AFRICAN ACTIVISTS RECLAIM HuMAN RIGHTS TO CHALLENGE GLOBAL POVERTY (Lucie E. White \& Jeremy Perelman eds., 2011).

135. See Champagne, supra note 133.

136. See ANAYA, supra note 1, at 105-31 (providing an overview of implementation and enforcement mechanisms, including the implementation of the UNDRIP); see also id. at 145-82 (describing ILO Supervisory System); id. at 194-214 (describing CERD); id. at 215-50 (describing adjudication by the Human Rights Committee under ICCPR Optional Protocol); id. at 264-319 (providing cases and reports of the Inter-American Court and Commission of Human Rights).

137. See, e.g., Joel Wainwright \& Joe Bryan, Cartography, Territory, Property: Post-Colonial Reflections on Indigenous Counter-Mapping in Nicaragua and Belize, 16 CULTURAL GEOGRAPHIES 153 (2009). 
conflict. $^{138}$ To the extent that human rights regimes promote the recognition of indigenous resources as fixed legal entitlements protected by the laws of states, they may seem to inflame, rather than resolve, issues endemic to the colonial experience. ${ }^{139}$

\section{The Myths and Consequences of Cultural Cohesion}

The unique nature of indigenous rights and the manner in which they are often articulated has given rise to several criticisms about how an international human rights regime based on a concept of "indigeneity"-however broadly defined-will interact with, reify, and perhaps even stagnate indigenous cultures.

One strand of this critique asserts that the concept of "culture" is itself problematic and misused in the indigenous rights movement. ${ }^{140}$ In essence, the concern is that deploying unique cultural attributes as a basis for claims of indigenous rights might have a narrowing and confining effect. As one author puts it, "right to culture claims, when successful, threaten to limit the groups that might qualify for protection, force groups to overstate their cultural cohesion, and limit indigenous economic, political, and territorial autonomy." ${ }^{141}$ In other words, indigenous groups' insistence on and adherence to these ideals may unduly confine efforts at true cultural evolution, selfdetermination, economic development, and other rights. ${ }^{142}$

138. See Joe Bryan, Dilemmas of Indigenous Land in Awas Tingni v. Nicaragua, ANTHROPOLOGY NEWS, Sept. 2006, at 22.

139. See id.

140. In a provocative new book, Karen Engle draws on the work of Gyatri Spivak to argue that indigenous human rights advocates are inappropriately employing "strategic essentialism" to characterize indigenous demands in terms of certain cultural attributes, particularly attachment to land. ENGLE, supra note 42, at 10-13. She argues that the decision to frame contemporary struggles in terms of "human rights to culture" is an attempt, unsuccessful in her view, to mediate the tension between the individualist, Western conception of human rights and the indigenous interests in communal land and traditional economic, social, and cultural practices. Id. at 13.

141. See id. Engle's concern is the subordination of indigenous "development" goals to a "cultural" agenda, which she sees as an "unintended consequence" of the indigenous rights movement. Id. at 7-13. For a somewhat different view of the role of human rights in indigenous development issues, see Lillian Aponte Miranda, The Role of International Law in Intrastate Natural Resource Allocation: Sovereignty, Human Rights, and Peoples-Based Development, 45 VAND. J. TRANSNAT'L L. 785, 792 (2012) (arguing that "an emerging human rights approach based on the substantive land and resource rights of peoples supports a peoples-based model of development potentially capable of more readily alleviating conditions of inequity and continued subordination for historically marginalized communities").

142. Engle is not alone in her view that indigenous identity is a problematic basis on which to claim rights. Anthropologists often criticize "culture" in this context, expressing the view that modern hybridities undermine the connection between indigeneity and legal rights. See Adam Kuper, The Return of the Native, 44 CURRENT ANTHROPOLOGY 389, 395 (2003) (arguing that when indigenous peoples "demand recognition for alternative ways of understanding the world," they do so "ironically enough ... in the idiom of Western culture theory"). 
A second strand of the culture critique focuses on conflicts that may arise within communities that purport cultural cohesion-what this Essay will later term "paideic nomos"-particularly when those cultural practices are enforced by "authoritative interpretations." 143 The concern is that, to the extent tribal autonomy empowers a collective right to govern through customary law, it challenges the fundamental precepts of international human rights law. ${ }^{144}$ As Martha Minow observes, "One of the touchiest points of contention involves whether individuals or groups are the primary unit of analysis and protection for human rights." "145 In the individual-centered view, international human rights law is meant to protect the individual against the state; thus, where the language of human rights has been employed to facilitate indigenous selfgovernance, it may have the effect of immunizing indigenous groups from human rights accountability. ${ }^{146}$ This could potentially lead to the exclusion or suppression of dissident voices. ${ }^{147}$

This critique has taken on particular resonance in countries that have relied on international human rights regimes_-bolstered by the UNDRIP in some instances - to advance collective indigenous rights and tribal autonomy. Cases where individuals face discrimination, exclusion, or even oppression within their tribal communities, perpetuated by the tribal authorities to which they are subject, are percolating up from the tribal level to gain prominent attention. ${ }^{148}$ From Mexican villages where indigenous women are denied the right to run for office under tribal law, ${ }^{149}$ to Indian tribes that pass membership along gender-based bloodlines, ${ }^{150}$ to Micronesian cultures that maintain rigid caste systems to organize village life, ${ }^{151}$ the stories of indigenous individuals

143. See Resnik, supra note 24, at 27.

144. See id. at $48-50$.

145. Martha Minow, Is Pluralism an Ideal or a Compromise?: An Essay for Carol Weisbrod, 40 CONN. L. REV. 1287, 1306 (2008).

146. See Wenona T. Singel, Indian Tribes and Human Rights Accountability, 49 SAN DIEGO L. REV. 567, 585 (2012). As one commentator writes, "autonomous rule by indigenous groups has, in some countries, created de facto states within states, which effectively shields indigenous communities from any obligation to protect the fundamental rights of their individual members who remain particularly vulnerable to the will of the collective group." Rebecca Gross, The "I" in Indigenous: Enforcing Individual Rights Guarantees in an Indigenous Group Rights Context, 23 N.Y. INT’L L. REV. 65, 67 (2010). For a discussion of how tribes have dealt with the incorporation of individual rights protections into indigenous communities, see Carole E. Goldberg, Individual Rights and Tribal Revitalization, 35 ARIz. ST. L.J. 889, 895-98 (2003) (discussing the general process by which tribes adopted individual rights provisions).

147. See Madhavi Sunder, Cultural Dissent, 54 StAn. L. ReV. 495 (2001).

148. See Singel, supra note 146, at 585.

149. See Lorraine Orlandi, Three Times the Suffering, LATIN AMERICA PrEss (Mar. 6, 2008), http://lapress.org/articles.asp?item=1\&art=5525.

150. See Riley, Illiberalism, supra note 18, at 810-13 (discussing Santa Clara Pueblo v. Martinez, 436 U.S. 49 (1978), and the patrilineal membership regime of the Pueblo).

151. See Larry Wentworth, The International Status and Personality of Micronesian Political Entities, 16 ILSA J. INT'L L. 1 (1993); Richard C. Paddock, Pocket Change for Giants, L.A. TIMES (June 30, 2006), http://articles.latimes.com/2006/jun/30/world/fg-yap30. 
within tribal communities continue to emerge, highlighting a central tension in international human rights law as applied to self-governing indigenous groups: how to protect the individual civil and political rights of tribal members while simultaneously advancing indigenous self-government and, concomitantly, indigenous peoples' cultural survival. ${ }^{152}$

All of these critiques are deeply resonant and important in the indigenous context, and many unanswered questions remain. To date, there has been less empirical data gathered on the impact of indigenous rights law than on the impact of international law more broadly or its other subfields. ${ }^{153}$ Accordingly, while we agree there are legitimate complaints about indigenous rights law, we contend the critiques are either incomplete or premature. It is possible that they will prove unduly skeptical of indigenous rights law insofar as they fail to fully account for the instances in which indigenous peoples are deeply and consciously involved in architecting a human rights system that bridges - or at least aspires to bridge-Western and indigenous ideals, mechanisms, and outcomes at every level.

As we have suggested above, indigenous peoples historically have been deeply involved in international human rights advocacy and have obtained the knowledge of its language and processes to address their needs as peoples. This history suggests that indigenous peoples are not naïve about the contradictions inherent in the human rights movement; ${ }^{154}$ to the contrary, preliminary assessments indicate they are acknowledging and addressing these challenges on their own terms. ${ }^{155}$

Contemporarily, just as indigenous peoples deploy human rights law to support claims for natural resources, religious freedoms, and equality against states, they are also using the language and instruments of human rights to inspire internal reflection on tribal governance. Indigenous scholars and tribal

152. Will Kymlicka has long engaged the tensions at the intersection of liberal theory and multiculturalism, with a focus on reconciling individual versus group rights. WILL KYMLICKA, Multicultural Citizenship: A LiBERAL THEORY OF MiNORITY RIGHTS 166-70 (1995); WiLL KYMLICKA, LIBERALISM, COMMUNITY AND CULTURE 196-98 (1989); see also, Minow, supra note 145, at 1307-08 (discussing the work of Kymlicka and the questions raised by Santa Clara Pueblo); Riley, Illiberalism, supra note 18, at 80-81. See generally Riley, Governance, supra note 18. As our previous work describes, these questions are of particularly pressing concern in the United States in light of the Supreme Court's ruling in Santa Clara Pueblo.

153. Cf. Oona Hathaway \& Scott J. Shapiro, Outcasting: Enforcement in Domestic and International Law, 121 YALE L.J. 252, 258 (2011) (engaging in a detailed examination of the ways in which international law impacts state behavior).

154. See, e.g., Gerald Torres, Indigenous Peoples, Afro-Indigenous Peoples and Reparations, in REPARATIONS FOR INDIGENOUS PEOPLES: INTERNATIONAL AND COMPARATIVE PERSPECTIVES 117 (Federico Lenzerini ed., 2008) (analyzing the contested status of “afro-indigenous” peoples in land claims in "Anglo and Latin America”).

155. See Anaya, supra note 13, at 108 ("Historically, international law can be seen as complicit in patterns of colonization, ultimately upholding the sovereignty asserted by colonizing states over indigenous peoples and their lands.”). 
leaders, for example, are developing proposals for dispute resolution mechanisms to address precisely the kinds of individual rights claims ${ }^{156}$ and intertribal disputes ${ }^{157}$ that seem most problematic today. Similarly, indigenous peoples and advocates are deeply and consciously engaged with questions of identity and culture as they relate to economic development, land claims, and other matters. ${ }^{158}$ Admittedly few of these deep conflicts-between the individual and the collective, among tribes, or between cultural and economic needs - have been satisfactorily resolved. ${ }^{159}$ As we have noted in previous works, indigenous communities are struggling with these challenges. ${ }^{160}$ Where we see great promise is at the confluence of indigenous traditions and human rights, a space in which indigenous peoples may be able to develop approaches to resolving these contemporary problems. This is a critical aspect of the jurisgenerative process, as we describe below.

II.

Nomos, NARRATIVE, AND THE DECOLONIZATION OF HuMAN Rights LAW

In his seminal work Nomos and Narrative, Robert Cover characterized paideic communities as those that "live within the complex encodings of commitments." 161 In Cover's language, such communities are uniquely jurisgenerative — or law-creating — simply because the very act of living daily

156. See Singel, Accountability, supra note 146, at 611-25 (proposing an inter-tribal treaty system to resolve tribal claims).

157. See, e.g., Davis Washines, Columbia River Fishing Site Disputes, DIPNETTER (May 2011), http://www.critfc.org/wp-content/uploads/2012/11/2011_05.pdf (describing the development of a dispute resolution process to address conflicts among tribal members and between tribes, with respect to fishing rights arising out of both treaties and customary tribal law).

158. See, e.g., Lorie M. Graham, An Interdisciplinary Approach to American Indian Economic Development, 80 N.D. L. REV. 597, 599-628 (2004) (describing the right to development as a human right that requires nuanced analysis of social, cultural, and other conditions in indigenous context); see also John A. Cordes, Mining and Indigenous Peoples, 1997 INT’L RESOURCES L. no. 2, paper 9B, 9B30 (discussing "development with identity" in mining activities).

159. See, e.g., Jessica Jones, Cherokee by Blood and the Freedmen Debate: The Conflict of Minority Group Rights in a Liberal State, 22 NAT'L BLACK L.J. 1 (2009) (discussing the dispute between certain Cherokees of African descent and the Cherokee Nation regarding enrollment status); see also Greg Rubio, Reclaiming Indian Civil Rights: The Application of International Human Rights Law to Tribal Disenrollment Actions, 11 OR. REV. INT'L L. 1 (2009) (applying international human rights standards to internal indigenous matters).

160. See generally Kristen A. Carpenter, Individual Religious Freedoms in American Indian Tribal Constitutional Law, in THE INDIAN CIVIL Rights ACT AT FORTY, supra note 18, at 159 (identifying and evaluating various tribal constitutional approaches regarding individual claims for religious freedom against tribal governments); Kristen A. Carpenter \& Ray Halbritter, Beyond the Ethnic Umbrella and the Buffalo: Some Thoughts on American Indian Tribes and Gaming, 5 GAMING L. REV. 311 (2001) (recognizing the challenge of respecting tribal identity and culture while pursuing economic development); Riley, Governance, supra note 18 (describing conflicts between individual tribal members and tribes).

161. Cover, supra note 19, at 29 (describing how Mennonite communities align their "sacred narratives" with their conceptions of law). 
life entails law creation. ${ }^{162}$ In this Section, we draw on Cover's iconic work first to describe the uniquely jurisgenerative features of self-governing indigenous communities. We then discuss the intersection of Cover's theory with the work of theorists and activists concerned with the "decolonization" of laws that have cabined the possibilities and rights of the world's indigenous peoples. ${ }^{163}$ We highlight this intersection to lay the groundwork for understanding the observable trend in Native governance-which we describe using detailed examples in Part III-toward an increased focus on international human rights law as a catalyst for jurisgenesis within indigenous communities.

\section{A. Robert Cover and the Nomos and Narrative of American Indian Nations}

Cover's Nomos and Narrative articulated a thick ${ }^{164}$ theory around the nomos, or "normative universe," where "law becomes not merely a system of rules to be observed, but a world in which we live." 165 Cover focused on what he described as "paideic" communities: those that "live within the complex encodings of commitment-their sacred narratives - that ground the understanding of the law that they offer." ${ }^{\prime 66}$ For Cover, these groups were defined as those for whom life, culture, religion, and the daily routines of being a human in a social community are deeply intertwined with religious belief and practice; he offered Mennonites, Orthodox Jews, and the Amish as examples. $^{167}$

Cover extended his ideas to American Indian tribes only by footnote, ${ }^{168}$ but subsequent scholars have built on his work to describe the paideic nature of indigenous groups, particularly those for whom the sacred and the secular are

162. Id. at 15-16 ("Thus it is that the very act of constituting tight communities about common ritual and law is jurisgenerative by a process of juridical mitosis. New law is constantly created through the sectarian separation of communities. The 'Torah' becomes two, three, many Toroth as surely as there are teachers to teach or students to study. The radical instability of the paideic nomos forces intentional communities_communities whose members believe themselves to have common meanings for the normative dimensions of their common lives - to maintain their coherence as paideic entities by expulsion and exile of the potent flowers of normative meaning.”).

163. This "decolonization" literature represents an intellectual thread running most prominently through scholarship on "settler colonial” states. See, e.g., Wolfe, supra note 52; Wolfe, supra note 62; Patrick Wolfe, The Settler Complex: An Introduction, 37 AM. INDIAN CULTURE \& RES. J. 1 (2013).

164. See JOHN RAWLS, A THEORY OF JUSTICE 395-99 (1971) (discussing “thin” and “full” conceptions of the good); see also Adina Schwartz, Moral Neutrality and Primary Goods, in JOHN RAWLS: CRITICAL ASSESSMENTS OF LEADING PHILOSOPHERS VOL. II 137, 141 (Chandran Kukathas ed., 2003) (characterizing Rawls’s dual conceptions of the good as “thin” and "thick” theories).

165. Cover, supra note 19, at 4-5.

166. Id. at 29; see also Resnik, supra note 24, at 20-22 (applying Cover's theory to the debate about whether Muslim girls should be permitted to wear headscarves in French public schools).

167. Resnik, supra note 24, at 27.

168. Cover, supra note 19, at 32 n.94 ("Respect for a degree of norm-generating autonomy has also traditionally been incident to the federal government's relations with Indian tribes.”). 
inextricably intertwined. ${ }^{169}$ One oft-cited example is that of the traditional Pueblos of the Southwest, who still maintain theocratic governments. For these tribes, there is no separation between the spiritual and secular orders, and leaders are chosen according to secret ritual, with rights and duties set and maintained in private. ${ }^{170}$

Robert A. Williams Jr. was one of the first indigenous legal theorists to embrace Cover and use his work as a vehicle for richer understanding of tribal peoples as deeply jurisgenerative. Williams tied Cover's work to tribal sovereignty as conceived in the United States-specifically focusing on the right of reservation Indians to make their own laws and be governed by them. ${ }^{171}$ In this sense, self-determination and jurisgenesis intertwine, as both recognize the right of Indian people to govern themselves according to their "shared normative commitments." 172 Thus, the paideic nomos of Indian nations is facilitated and maintained through the restoration and continuation of indigenous peoples' rights to live in accordance with their own laws and traditions. $^{173}$

To that end, Cover's work and the subsequent extensions of his theory contemplating indigenous peoples as paideic communities provide the theoretical grounding for this Essay. We find that considering indigenous and tribal peoples around the world through the lens of jurisgenesis helps in understanding indigenous law-creation and in grasping indigenous peoples' historical and contemporary status as largely distinct from the nation-states that threaten to engulf them. The phenomenon we have identified further reveals that law-creation is occurring at every "level" at which indigenous peoples make and experience law: tribal, national, and international. Critical to understanding the jurisgenerative moment, however, is realizing that this process is neither discrete nor confined to each respective "level," but migrates to other planes of law-production, creating an entirely new nomos within which indigenous rights are central. ${ }^{174}$ The examples provided in Part III illustrate this process.

Though we find Cover's work critical to the theoretical underpinnings of the jurisgenerative moment, it does not stand alone. As we describe in Part B below, Cover's foundational theories combine with transformative shifts in

169. See generally Resnik, supra note 24; Angela R. Riley, Recovering Collectivity: Group Rights to Intellectual Property in Indigenous Communities, 18 CARDOZO ARTS \& ENT. L. REV. 175 (2000) (discussing the interconnected of the sacred and secular in many indigenous religious worldviews).

170. See Riley, Governance, supra note 18, at 1100-01.

171. Williams, supra note 49, at 149; see also Williams v. Lee, 358 U.S. 217 (1959) (holding that a tribal court, rather than an Arizona state court, had jurisdiction to hear a civil suit because the action arose on a Navajo reservation).

172. See Williams, supra note 49 , at 149 \& n.7.

173. Id. at 149.

174. See generally Resnik, supra note 7. 
decolonization literature and practice to provide an even richer and fuller picture of the jurisgenerative moment in indigenous rights law.

\section{B. The Postcolonial Convergence}

In the past twenty years, most prominently in the so-called settler nations of Canada, Australia, New Zealand, and the United States, indigenous studies scholars have increasingly engaged decolonization theory. ${ }^{175}$ Legal scholars in the United States, in particular, have focused on the concept of decolonization to better understand all the ways in which the exceptional position of Indian tribes within the United States has threatened the full exercise of sovereignty and their equality within the federal system. Because a grasp of this exceptionalism is key to understanding the impact of both colonial law and efforts to decolonize the law, we provide here (1) a brief account of the relevant history and (2) a sketch of the decolonization literature, in both cases focusing particular attention on the situation of American Indian tribes.

\section{American Indian Tribes and the United States}

Indian nations are anomalous within the federal system. ${ }^{176}$ Tribes are preconstitutional and have never been formally incorporated into the American constitutional framework, allowing them to maintain a separate sovereignty that defines their relationship with the United States. ${ }^{177}$ But American laws advancing Indian autonomy have increasingly come under scrutiny as potentially violative of equal protection norms, which focus on formal equality. ${ }^{178}$ Thus, as one author has pointed out, American "[c]onstitutional supremacy is a great achievement of Americans but a threat to Native American tribes." 179 In other words, “[e]qual protection jurisprudence provides for equality of assimilation into the constitutional reality," but "assimilation into the jurisdictional monopoly destroys rather than benefits tribes.”"180

175. See generally Wolfe, supra note 163.

176. See United States v. Kagama, 118 U.S. 375, 381 (1886); see also Matthew L.M. Fletcher, Tribal Membership and Indian Nationhood, 37 AM. INDIAN L. REV. 1, 1-2 (2013) (describing the "anomalous character of Indian tribes" and the conflicts this poses in an increasingly "color-blind[]" society).

177. See generally Singer, supra note 57.

178. The Supreme Court's recent opinion in Adoptive Couple v. Baby Girl, 133 S. Ct. 2552, 2565 (2013), reveals the Court's increasing skepticism of laws, like the Indian Child Welfare Act (ICWA), that are meant to preserve and advance Indian autonomy, sovereignty, and cultural survival. See Indian Child Welfare Act of 1978, 25 U.S.C. §§ 1901-63 (2012). The Court decided against the interpretation of ICWA advanced by the birth father and the tribe, warning that such an interpretation "would raise equal protection concerns." Adoptive Couple, 133 S. Ct. at 2565; see also Krakoff, supra note 63, at 1051-90 (detailing the historical context in which tribes as political sovereigns arose and the potential challenges raised by contemporary equal protection doctrine).

179. Milner S. Ball, Stories of Origin and Constitutional Possibilities, 87 MiCH. L. REV. 2280, 2306 (1989).

180. Id. 
This unique history and political status means that Indian tribes all too often find justice elusive, as they cannot be reconciled as either sufficiently within or without the federal system. ${ }^{181}$ Indeed, the entire field of American Indian law is constitutionally, historically, and jurisprudentially characterized by exceptionalism. ${ }^{182}$

This status creates a paradox for Indian nations whose presence in what is now the United States long predates European contact. This continent-Turtle Island to many ${ }^{183}$-is the setting for the creation stories of the indigenous peoples who call it home. The sacred places that define their spiritual existence-much like Mecca, Jerusalem, and Mount Calvary to other religious adherents ${ }^{184}$-are here on this continent. For Native people, every component of their peoplehood is tied up in and defined by the lands from which they originated. ${ }^{185}$ In indigenous cultures, these lands are not only historical territories; they are also sacred places giving rise to human life, societal values, subsistence practices, and religious beliefs. ${ }^{186}$ Around the globe, remarkable natural landscapes-Uluru (Ayers Rock) in Australia, Mato Tipila (Devil's Tower) in Wyoming, Machu Picchu in Peru, among countless othersconstitute sacred sites for indigenous peoples. ${ }^{187}$

American Indians were peoples invaded, whose sacred places were taken from them by force (of law, starvation, or war), and these are the places to which many of them still seek to return. ${ }^{188}$ Thus, in the conquest of America, indigenous peoples resisted colonization in part because of the deep cultural and spiritual connections they maintained to the physical territory itself. These connections to land form the political relationship of American Indians with the United States. In this context, American Indians' intense patriotism, manifested in overrepresentation in the armed forces and active participation in foreign wars, though perhaps baffling to non-Indians initially, should be understood as consistent with the sincere connection that American Indians feel with their homeland. ${ }^{189}$

181. Compare Lyng v. Nw. Cemeteries Ass'n, 485 U.S. 439 (1988) (holding that the First Amendment does not protect the Free Exercise claims of Indians to sacred lands that are owned by the federal government), with Tee-Hit-Ton Indians v. United States, 348 U.S. 272 (1955) (holding that Indian land claims are exceptional and, therefore, a taking of aboriginal title is not a "taking" according to the Fifth Amendment of the Constitution).

182. See Philip P. Frickey, (Native) American Exceptionalism in Federal Public Law, 119 HARV. L. REV. 433, 434-35 (2005). (2010).

183. See Duane Champagne, Notes from the Center of Turtle Island, at viii-ix

184. See Carpenter, Sacred Sites, supra note 18, at 1062-63.

185. See Carpenter et al., In Defense, supra note 18.

186. See id.

187. See id.

188. See United States v. Sioux Nation, 448 U.S. 371 (1980).

189. See Lindsay F. Holiday et AL., U.S. DEPT. Veterans AfFairs, AMERICAN INDian and Alaska Native Veterans: Lasting Contributions 6 (2006); see also Angela R. Riley, Indians and Guns, 100 GEO. L.J. 1675, 1702-03 (2012). 
The incongruity created by the process of settler colonialism is perhaps most prevalent in legal development within Indian tribes. Consider, for example, the challenges that indigenous peoples face in maintaining or adapting contemporary governmental institutions. To achieve recognition and legitimacy in the eyes of outsiders, tribal institutions oftentimes must emulate the state and federal systems or risk being considered too far afield from prevailing notions of American constitutionalism to be tolerable. ${ }^{190}$ On the other hand, if tribal institutions, particularly tribal courts, merely mirror the state and federal systems, and they do not reflect indigenous laws and values, the process of colonization has truly been complete. ${ }^{191}$

Despite the consequences of colonization, however, for the last several hundred years Native nations within the United States have engaged in their own process of law-making, revitalization, and institution-building within the bounds of the settler colonial state. ${ }^{192}$ Though many indigenous governing systems, religions, languages, and cultures survived throughout history, Indian peoples have undoubtedly been shaped by the colonial mindset manifest in American society and unequivocally embedded in American law. Unquestionably, then, one design feature of indigenous governance in contemporary America can accurately be described as a reaction to the processes of colonization.

Thus we find that indigenous governance in a colonized world is seldom free to evolve organically, as it is so often grown in the shadow of colonialism. ${ }^{193}$ Because of the influence of colonization, tribes may overtly resist changes otherwise desirable that may be perceived as too Western. ${ }^{194}$ In other cases, tribes-perhaps even unknowingly at times-develop rules and legal institutions that are directly born out of reaction to colonial rule. ${ }^{195} \mathrm{We}$ recognize, of course, that no government can distinguish itself from the political and historical milieu in which it formed. Nor do we mean to suggest that all changes in indigenous cultures from the point of contact until contemporary times must be the result of colonial forces. ${ }^{196}$ At the same time, Indian nations continue to wrestle with the overriding plenary power of Congress - a situation that is very different from, for example, that of the

190. See Riley, Illiberalism, supra note 18.

191. See id.

192. See Stephen Cornell \& Joseph P. Kalt, Reloading the Dice: Improving the Chances for Economic Development on American Indian Reservations, in WHAT CAN TRIBES DO?: STRATEGIES AND INSTITUTIONS IN AMERICAN INDIAN ECONOMIC DEVELOPMENT 1, 17-21 (Stephen Cornell \& Joseph P. Kalt eds., 1993) (describing cultural "match" as a factor in successful nation-building by tribes).

193. See Anaya, supra note 13, at 108 (describing the colonial vestiges of law); Robert B. Porter, Pursuing the Path of Indigenization in the Era of Emergent International Law Governing the Rights of Indigenous Peoples, 5 YALE HuM. RTS. \& DEV. L.J. 123, 123 (2002).

194. Cf. CHAMPAGNE, supra note 183, at 50.

195. See Riley, Governance, supra note 18, at 1077-78.

196. See CHAMPAGNE, supra note 183, at 49-50. 
United States, which has long enjoyed relative independence in making its own law. ${ }^{197}$

\section{The Decolonization Literature}

Indigenous legal scholars have undertaken vociferous criticism of the body of law devised by the federal government to "manage" the affairs of Indian tribes_-so-called federal Indian law. As a way to contemplate freeing tribal governments from colonial binds, legal scholars have engaged in a decades-long scholarly debate about how best to “decolonize” Indian law. ${ }^{198}$ These critiques are framed in opposition to the United States' colonial domination of Indian peoples and its continued assertion of power over Indian tribes. This assertion of power, at times, appears virtually limitless and without corresponding duties to honor the obligations of the sacred trust established between the U.S. government and Indian nations. Efforts to decolonize Indian law include wide-ranging proposals for action taken by American Indian tribes, from resisting American citizenship, ${ }^{199}$ to dismantling the doctrine of discovery, ${ }^{200}$ to using tribal courts to limit colonization's reach within tribal communities. $^{201}$

One approach has gained traction in recent years and holds particular resonance for this inquiry. Numerous scholars and activists have repeatedly advocated for increased engagement with the international arena to advance indigenous rights and to reconceptualize the status of indigenous groups within nation-states. $^{202}$ They have long noted the absence of an appeal to international human rights principles as a symptom of continued colonial domination. ${ }^{203}$ But today, scholars and advocates are more actively embracing the confluence of indigenous and international law, particularly as set forth in the UNDRIP, and they point to it specifically as a vital tool in the decolonization movement. ${ }^{204}$ Some commentators note, albeit with caution, that the UNDRIP reflects a distinctly indigenous influence on process and substance, that has in turn impacted both domestic and international law. ${ }^{205}$

In the past few decades, increased attention to indigenous selfgovernance, articulation of decolonization theories, postcolonial political shifts,

197. See Resnik, supra note 7, at 1583.

198. See Robert N. Clinton, Redressing the Legacy of Conquest: A Vision Quest for a Decolonized Federal Indian Law, 46 ARK. L. REV. 77, 121 (1993).

199. See Robert B. Porter, The Demise of the Ongwehoweh and the Rise of the Native Americans: Redressing the Genocidal Act of Forcing American Citizenship upon Indigenous Peoples, 15 HARV. BLACKLETTER L.J. 107, 175 (1999).

200. See Williams, supra note 22, at 293.

201. See Robert N. Clinton, Tribal Courts and the Federal Union, 26 WiLlametTE L. REV. 841, 865-66 (1990).

202. See Anaya, supra note 13, at 108; Williams, supra note 106, at 660.

203. See Anaya, supra note 13.

204. See HENDERSON, supra note 25, at 11-12.

205. Id. 
active engagement by indigenous peoples, and global reflection on the rights of marginalized peoples have converged. And this convergence-some presenting as internal evolutions, others as exogenous shocks-has inspired a powerful postcolonial opportunity for indigenous peoples. In this sense, we see the jurisgenerative moment as a descriptively demonstrable phenomenon that is shaping and supporting the generation of tribal law itself.

In the final Part III of this paper, we turn our attention to the way in which indigenous groups are engaging in jurisgenerative processes at the tribal, national, and international levels. In addition, we provide a theoretical account to describe how this amalgam of legal norms meet, combine, and influence one another to produce a genuinely jurisgenerative moment in human rights.

III.

\section{INDIGENOUS PEOPLES AND THE JURISGENERATIVE MOMENT IN} HUMAN RIGHTS

Across the globe, indigenous peoples are and historically have been marginalized, existing largely outside the political structures of the nationstates that have formed around them. Statistics demonstrate that today they are among the world's poorest, unhealthiest, and least educated people. ${ }^{206}$ In addition, they are often subjected to violence and the loss of livelihood and property. ${ }^{207}$ Ongoing discrimination is a key contributor to indigenous peoples' shared oppression, particularly as nation-states authorize mineral exploration and extraction on indigenous lands, oftentimes without consultation, consent, or compensation. $^{208}$

As indigenous peoples and their advocates consider strategies for addressing these past and ongoing harms, it is critically important to assess whether and how international law impacts indigenous rights and experiences on the ground. ${ }^{209}$ We note that, given the recent vintage of the international human rights movement, it is too early to make any conclusive or sweeping judgments; nevertheless, we contend that a distinctly jurisgenerative process of mutual influence is apparent. For example, global and regional human rights tribunals are relying on indigenous customary law as a basis for indigenous rights. States are beginning to accept human rights norms derived from

206. See Secretariat of the Permanent Forum on Indigenous Peoples, U.N. Dept.

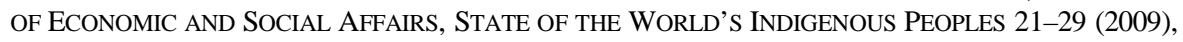
available at http://www.un.org/esa/socdev/unpfii/documents/SOWIP_web.pdf.

207. See id. at 29-39.

208. See Jonathan Kaiman, Ecuador Auctions off Amazon to Chinese Oil Firms, GuARDIAN (March 26, 2013), http://www.guardian.co.uk/world/2013/mar/26/ecuador-chinese-oil-bids-amazon ("Indigenous groups claim they have not consented to oil projects, as politicians visit Beijing to publicise bidding process.”); Simon Romero, Violence Hits Brazil Tribes in Scramble for Land, N.Y. TIMES, June 10, 2012, at A6 (describing the killing of indigenous peoples for their lands).

209. See, e.g., Goodman \& Jinks, supra note 27, at 623-30; Graham \& Wiessner, supra note 6; Oona Hathaway, Do Human Rights Treaties Make a Difference, 111 YALE L.J. 1935 (2002). 
international and indigenous sources in their own judicial decisions, constitutions, and other activities. And tribal courts, councils, and commissions are more frequently citing international instruments as a source of tribal rights and responsibilities.

In Sections A, B, and C, we discuss examples of the jurisgenerative moment as exemplified in international, domestic, and indigenous legal systems, demonstrating the mutual and dynamic influence of various sources of law, legal actors, and institutions. Our discussion focuses not only on cases that are "victories" for indigenous parties, but rather identifies and describes examples that illustrate the variety of indigenous peoples' engagement with human rights law.

\section{A. In International Law}

Scholars have argued persuasively that indigenous peoples have had a profound impact on international human rights law. ${ }^{210}$ As one commentator notes, "indigenous peoples have played a significant role in changing the legal landscape of human rights," yet they have done so "in ways that are not necessarily captured by mainstream accounts of non-state actor participation in international norm-building and decision-making." ${ }^{211}$ Indeed, it is through their sheer persistence in advocacy and insistence on "discursive strategies" that indigenous peoples have pushed international law to reflect indigenous norms and values, at least to some degree. ${ }^{212}$

Through their participation in myriad initiatives, indigenous peoples are pressing international organizations to be responsive to indigenous norms, values, and claims in their standard-setting work. ${ }^{213}$ As described above, activities leading up to the adoption of the UNDRIP offer perhaps the most transformative example of indigenous voices in international lawmaking. ${ }^{214}$ But many other advocacy initiatives illustrate similarly engaged participation, including the Convention on Biodiversity's working group on traditional

210. See generally Anaya, supra note 13.

211. See Miranda, supra note 21, at 203-04.

212. See RHIANNON MORGAN, TRANSFORMING LAW AND INSTITUTION: INDIGENOUS PEOPLeS, THE UNITED NATIONS AND HuMAN RighTS 117-38 (2011) (arguing that indigenous peoples' advocacy has "reconfigured” human rights through "discursive” and other strategies).

213. In one leading example, indigenous peoples have formed their own international organization, the Indigenous Circumpolar Conference, designed to promote unity and international advocacy among over 160,000 Inuit people living in several nation-states. See INUIT CIRCUMPOLAR CounCIL, http://www.inuit.org (last visited Nov. 10, 2013).

214. See Luis Enrique Chávez, The Declaration on the Rights of Indigenous Peoples Breaking the Impasse: The Middle Ground, in MAKING THE DECLARATION WORK, supra note 25, at 96; Siegfried Wiessner, Indigenous Self-Determination, Culture, and Land: A Reassessment in Light of the 2007 UN Declaration on the Rights of Indigenous Peoples, in INDIGENOUS RIGHTS IN THE AGE OF THE UN DECLARATION, supra note 128, at 31 (considering assertions of indigenous "voice" in international human rights law). 
knowledge; ${ }^{215}$ the World Intellectual Property Organization's Intergovernmental Committee on Intellectual Property and Genetic Resources, Traditional Knowledge and Folklore (IGC); ${ }^{216}$ the World Bank's Directive on Indigenous Peoples; ${ }^{217}$ the World Health Organization's indigenous peoples programs; ${ }^{218}$ and various climate change initiatives. ${ }^{219}$

In this Section, however, we focus specifically on jurisprudence arising from international and regional decision-making tribunals, including organs of the U.N., the Organization of American States (OAS), and other institutions. This examination reveals the influence of indigenous customary law in a diverse range of disputes: membership, property rights, equality, and others.

This phenomenon is remarkable on several grounds. First, the recognition of indigenous customary law has afforded greater protection of indigenous property rights, which are essential to self-determination, self-governance, and continued cultural existence. ${ }^{220}$ Second, considering that indigenous peoples' internal affairs - including matters bearing on family relations, religious life, and political leadership-are governed by indigenous customary law, the inclusion of these laws into international decision-making processes is critical to achieving meaningful equality and self-determination for indigenous peoples.

International dispute-resolution bodies were contemplating indigenous customary law as early as 1981, when the United Nations Human Rights Committee (HRC) considered Lovelace v. Canada, ${ }^{221}$ in which a Canadian Indian woman relied on indigenous, customary law to challenge in an international tribunal the sexually discriminatory rules of the Indian Act. ${ }^{222}$ Though the HRC ultimately decided the case on different grounds, ${ }^{223}$ this initial

215. See Traditional Knowledge, Innovations and Practices, CONVENTION ON BIOLOGICAL DIVERSITY, http://www.cbd.int/traditional/intro.shtml (last visited Nov. 10, 2013).

216. Intergovernmental Committee, WORLD InTELlectual PROPERTY ORGANiZATION, http://www.wipo.int/tk/en/igc (last visited Nov. 10, 2013).

217. WORLD BANK OPERATIONAL MANUAL § OP 4.10: Indigenous Peoples (2005).

218. The Health and Human Rights of Indigenous Peoples, WORLD HEALTH ORGANIZATION, http://www.who.int/hhr/activities/indigenous/en (last visited Nov. 10, 2013).

219. See Annalisa Savaresi, The Role of REDD in the Harmonisation of Overlapping International Obligations, in CLIMATE CHANGE AND THE LAW 391 (Erkki J. Hollo, Kati Kulovesi \& Michael Mehling eds., 2013) (describing indigenous peoples' participation in climate change and forest management practices).

220. See Kent McNeil, Indigenous Land Rights and Self-Government: Inseparable Entitlements, in BETWEEN INDIGENOUS AND SETTLER GOVERNANCE, 135, 135-37 (Lisa Ford \& Tim Rowse eds., 2013).

221. Lovelace v. Canada, Commc'n No. R.6/24, U.N. Doc. Supp. No. 40 (A/36/40) at 166 (July 30, 1981) [hereinafter Lovelace], available at http://www1.umn.edu/humanrts/undocs /session36/6-24.htm. The case has many parallels to the United States case of Santa Clara Pueblo $\mathrm{v}$. Martinez, 436 U.S. 49 (1978).

222. Lovelace, U.N. Doc. Supp. No. 40 (A/36/40), ๆ9 5-6. Note that both parties used competing visions of customary law to support their respective arguments.

223. The HRC largely based its decision on Article 27 of the ICCPR. ICCPR, supra note 94, art. 27, 999 U.N.T.S. at 171. 
foray into the use of indigenous customary law foreshadowed the coming trend of "law's migration" 224 from indigenous communities to international regimes. $^{225}$

In the years after Lovelace, some of the most groundbreaking indigenous rights decisions came out of regional human rights institutions, rather than through the United Nations. In the Americas, the Inter-American Commission of Human Rights and the Inter-American Court of Human Rights have been at the forefront of incorporating indigenous customary law into the growing body of indigenous human rights. ${ }^{226}$

The 2001 case of The Mayagna (Sumo) Awas Tingni Community v. Nicaragua (Awas Tingni) ${ }^{227}$ has taken its place as the Inter-American Court of Human Right's landmark case regarding indigenous rights. ${ }^{228}$ It involved a dispute over Nicaragua's grant of a thirty-year lease to a logging company on the ancestral lands of the Miskito, Rama, and Sumo peoples. ${ }^{229}$ After review, the Inter-American Commission on Human Rights filed the case in the Court on behalf of the indigenous groups. ${ }^{230}$ At first glance, the questions presented in Awas Tingni appear largely procedural in nature: whether, for example, Nicaragua had violated the American Convention on Human Rights by failing to "adopt[] effective measures to ensure the property rights of the

224. See generally Resnik, supra note 7.

225. For accounts of post-Lovelace legislation and advocacy, see, e.g., Sarah E. Hamill, McIvor v. Canada and the 2010 Amendments to the Indian Act: A Half-Hearted Remedy to Historical Injustice, 19 CONST. F. CONSTITUTIONNEL 75 (2010); Elizabeth Jordan, Residual Sex Discrimination in the Indian Act: Constitutional Remedies, 11 J.L. \& SOC. PoL'Y 213, 220 (1995); Wendy Moss, Indigenous Self-Government in Canada and Sexual Equality Under the Indian Act: Resolving Conflicts Between Collective and Individual Rights, 15 QUEEN's L.J. 279 (1990); INDIAN \& N. AFFAIRS CAN., DISCUSSION PAPER: CHANGES TO THE INDIAN ACT AFFECTING INDIAN REGISTRATION AND BAND MEMBERSHIP, MCIVOR V. CANADA 2-3 (2009), http://www.aadnc-aandc.gc.ca/DAM /DAM-INTER-HQ/STAGING/texte-text/mci_1100100032488_eng.pdf; see also Mahuika v. New Zealand, Commc'n No. 547/1993, U.N. Doc. CCPR/C/70/D/547/1993 (Oct. 27, 2000), available at http://www1.umn.edu/humanrts/undocs/547-1993.html (looking at Maori processes in determining that New Zealand's settlement of Maori fishing rights claims under the Treaty of Waitangi did not violate Maori equality); infra notes 297-303 and accompanying text.

226. For a full discussion of the differences between the Court (which may only exercise jurisdiction and issue legally binding opinions where the state concerned is a party to the Convention and also has accepted the optional jurisdiction of the Court, pursuant to Article 62 of the Convention) and the Commission (which may only issue recommendations), see generally ANAYA, supra note 1 , at 258-59; Dinah Shelton, Environmental Rights and Brazil's Obligations in the Inter-American Human Rights System, 40 GEO. WASH. INT’L L. REV. 733 (2009). (2001).

227. Mayagna (Sumo) Awas Tingni Cmty. v. Nicaragua, Inter-Am. Ct. H.R. (ser. C) No. 79

228. See, e.g., S. James Anaya \& Claudio Grossman, The Case of Awas Tingni v. Nicaragua: A New Step in the International Law of Indigenous Peoples, 19 ARIZ. J. INT'L \& COMP. L. 1 (2002).

229. See S. James Anaya, The Awas Tingni Petition to the Inter-American Commission on Human Rights: Indigenous Lands, Loggers, and Government Neglect in Nicaragua, 9 ST. THOMAS L. REV. 157, 157-58 (1996).

230. Awas Tingni, Inter-Am. Ct. H.R. (ser. C) No. 79 at 91. 
Community."231 But embedded in this inquiry was a second, crucial question: How are the property rights of the Community to be measured and defined?

Nicaragua contended that its indigenous residents could not have a recognized property interest in their ancestral lands because they lacked formal title. But, relying on the right to property as defined in the American Convention on Human Rights (the Convention), the Court disagreed. Looking to the indigenous groups' own system of allocating land as a source of law, ${ }^{232}$ the Court emphasized that "[a]mong indigenous peoples there is a communitarian tradition ... in the sense that ownership of the land is not centered on an individual but rather on the group."233 Moreover, "the close ties of indigenous people with the land must be recognized and understood as the fundamental basis of their cultures, their spiritual life, their integrity, and their economic survival." 234 The Court further noted that Nicaraguan law also recognized that indigenous individuals had possessory rights in their communal lands. ${ }^{235}$ Even in the absence of "real title," the Court concluded that the community's continuous possession of the land should suffice for official recognition and registration of its property rights. ${ }^{236}$

The Court's groundbreaking opinion-spawning what has been referred to

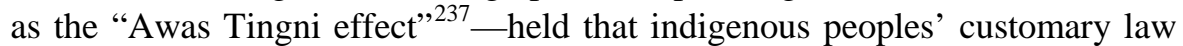
of land tenure could give rise to property rights pursuant to the Convention. ${ }^{238}$ The case has resonated through other similar Inter-American system claimssuch as the U.S. aboriginal title case of Dann v. United States ${ }^{239}$ — wherein the Commission relied on Awas Tingni's interpretation of the right to property to find that the United States had deprived the Danns of equal protection and

231. Id. $₫ 2$.

232. Id. $₫ 151$.

233. Id. $₫ 149$.

234. Id.

235. Id. $₫ 150$.

236. Id. ๆ 151-53.

237. See Luis Rodríguez-Piñero, The Inter-American System and the UN Declaration on the Rights of Indigenous Peoples: Mutual Reinforcement, in REFLECTIONS ON UNDRIP, supra note 25, at 457, 459-65.

238. The Court also found a corresponding state obligation to recognize indigenous land rights via demarcation. See Alexandra Xanthaki, Indigenous Rights in International Law over the Last 10 Years and Future Developments, 10 MELB. J. INT'L. L. 27, 32 (2009) (explaining that Awas Tingni "has been viewed as the definitive point" of reference in indigenous property rights). As Alexandra Xanthaki notes, "This was the first binding international decision to recognise such a collective right to indigenous peoples and to interpret the American Convention in such manner that recognises indigenous collective rights.” Id.

239. See, e.g., Dann v. United States, Case 11.140, Inter-Am. Comm'n H.R., Report No. 75/02, OEA/Ser.L./V/II.117, doc. 5 rev. 95 (2002). The Danns also took their case regarding mining and waste storage on sacred sites to the United Nations Committee on the Elimination of Racial Discrimination under its early warning and urgent action procedure. See CERD, Early Warning and Urgent Action Procedure: Decision 1(68), 68th Sess., Feb. 20-Mar. 10, 2006, ๆ 10, U.N. Doc. CERD/C/USA/DEC/1 (Apr. 11, 2006) [hereinafter CERD, Decision 1(68)] (urging the United States to "freeze ... desist from . . . [and] stop" actions being taken against the Western Shoshone peoples). 
procedural fairness in proceedings terminating their land titles. ${ }^{240}$ Then, in 2004, in Maya Indigenous Community of the Toledo District v. Belize, ${ }^{241}$ the Commission went further and formally adopted the Awas Tingni principle, affirming that states must effectively demarcate indigenous peoples' lands and that the "customary land tenure system [should] be taken into account in this process." 242

A subsequent string of cases in the Court reinforced the work of the Commission and even expanded on the principles laid out in Awas Tingni. In Yakye Axa Indigenous Community v. Paraguay, the Court amplified Awas Tingni and acknowledged the "close ties of indigenous peoples with their traditional territories and the natural resources therein associated with their culture." 243 In holding that they "must be safeguarded by Article 21 of the American Convention," the Court further expressed a desire to protect the indigenous groups' cultural, religious, and economic lifeways, including the means by which such values are passed through oral tradition. ${ }^{244}$ The Court followed up on Yakye Axa shortly thereafter, further clarifying the property rights of the Enxet-Lengua peoples in Sawhoyamaxa Indigenous Community v. Paraguay. $^{245}$

A subsequent cascade of cases expanded on the right to property principle. In Moiwana Community v. Suriname, the Court extended the contours of Awas Tingni, upholding indigenous peoples' right to property. ${ }^{246}$ The Court suggested that possession was not necessary for securing recognition of indigenous peoples' aboriginal title to ancestral lands, if "they have been deprived of" the right to use and enjoy those lands because of violence perpetrated by agents of the state. ${ }^{247}$ And Saramaka People v. Suriname ordered that a state "delimit, demarcate, and grant collective title over the territory" of an indigenous group, "in accordance with their customary laws."248

In all of these cases, it is apparent that the Inter-American Commission and Court are developing a jurisprudence of legally cognizable indigenous

240. See CERD, Decision 1(68), supra note 239, \ 134.

241. Maya Indigenous Cmty. of the Toledo District v. Belize, Case 12.053, Inter-Am. Comm'n. H.R., Report No. 40/04, OEA/Ser.L/V/II.122, doc. 5 rev.1 (2004).

242. Id. $\mid 132$.

243. Yakye Axa Indigenous Cmnty. v. Paraguay, Inter-Am. Ct. H.R. (ser. C) No. 125, ๆ 137 (June 17, 2005), available at http://www.corteidh.or.cr/docs/casos/articulos/seriec_125_ing.pdf.

244. Id.

245. Sawhoyamaxa Indigenous Cmnty. v. Paraguay, Inter-Am. Ct. H.R. (ser. C) No. 146, (March 29, 2006), available at http://www.corteidh.or.cr/docs/casos/articulos/seriec_146_ing.pdf.

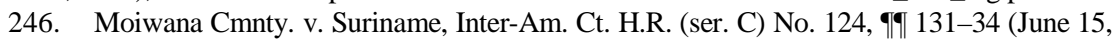
2005), available at http://www.corteidh.or.cr/docs/casos/articulos/seriec_124_ing.pdf.

247. Id. ๆ 134.

248. Saramaka People v. Suriname, Inter-Am. Ct. H.R. (ser. C) No. 172, ๆ 194 (Nov. 28, 2007), available at http://www.corteidh.or.cr/docs/casos/articulos/seriec_172_ing.pdf (emphasis added). 
rights under human rights instruments. As the Court described in Awas Tingni, the Court's "evolutionary interpretation of international instruments for the protection of human rights ... protects the right to property in a sense which includes ... the rights of members of the indigenous communities within the framework of communal property." 249 The subsequent opinions demonstrate that the jurisgenerative moment in Awas Tingni has persisted, along with a growing understanding that deep connections with particular lands are a constitutive aspect of indigenous cultures. The unique nature of the relationship between the people and the place dictates that a core feature of selfdetermination for indigenous groups includes respect for the right to continued existence on their traditional lands. ${ }^{250}$ Thus, the cases reach even further than they first appear, in that they acknowledge ongoing importance of the link between indigenous peoples and their lands, despite historical dispossession and colonization. ${ }^{251}$

In sum, the inclusion of indigenous customary law in cases with nationally binding impact is one defining aspect of the jurisgenerative moment. While there is enormous progress to be made, much has been gained, and much can be learned, from this bottom-up—and down again—jurisgenerative phenomenon.

\section{B. In Domestic Legal Systems}

In this Section, we focus on the myriad ways in which nation-states have begun to implement indigenous rights, as influenced by international human rights law, in the domestic sphere. ${ }^{252}$ This phenomenon is seen most clearly in the express adoption of international law through legislative, executive, and

249. Mayagna (Sumo) Awas Tingni Cmty. v. Nicaragua, Inter-Am. Ct. H.R. (ser. C) No. 79, I 14 (2001).

250. See Carpenter et al., In Defense, supra note 18, at 1032-38.

251. See id. at 1046-87 (articulating a theory of indigenous peoplehood and cultural stewardship of property). For detailed accounts of how indigenous rights to land have been denied by colonizing regimes, see BANNER, supra note 36; STUART BANNER, HOW THE INDIANS LOST THEIR LAND: LAW AND POWER ON THE Frontier (2005); ROBERT J. MILLER ET AL., DisCOVERING INDIGENOUS LANDS: THE DOCTRINE OF DISCOVERY IN THE ENGLISH COLONIES (2010). Still, there remain major questions about the extent to which indigenous claimants will receive remedies, in the form of actual land restitution and/or damages; whether rights to property will also connote selfgovernance over retained and reclaimed territories; and how such rights will be implemented in a way that truly benefits indigenous peoples and their neighbors.

252. States' implementations of international legal instruments - whether treaties, declarations, or otherwise - offer a direct path to effectuating human rights principles. See Hathaway, supra note 209, at 1940 (questioning the impact of treaties). But see Ryan Goodman \& Derek Jinks, Measuring the Effects of Human Rights Treaties, 14 EUR. J. INT’L L. 171 (criticizing Hathaway's study). Treaties may not be self-executing, however, and states arguably must ratify them to make them effective and binding. See, e.g., Lori F. Damrosch, A Comparative Look at Domestic Enforcement of International Tribunal Judgments, 103 AM. SOC’Y INT'L L. Proc. 39 (2009). Other questions concern the availability of private enforcement, even in domestic tribunals. See Oona A. Hathaway, Sabria McElroy \& Sara Aronchick Solow, International Law at Home: Enforcing Treaties in U.S. Courts, 37 YALE J. INT'L L. 51 (2012) (examining the question of whether treaties conferring private and public rights are self-executing). 
judicial law-making mechanisms. ${ }^{253}$ But this Section also highlights some of the less formal mechanisms by which nation-states adopt international law. For example, implementation of international human rights law in nation-states may occur through "persuasive" means, such as responding to invitations for submissions on complaints issued by the U.N. Human Rights Committee or the Inter-American Commission on Human Rights. ${ }^{254}$ Strides in human rights also transpire pursuant to "sociological" transitions, wherein state actors begin to adopt the beliefs and behaviors of the world community through a process of "acculturation., ${ }^{255}$ For example, it is now a relatively widespread practice for states to recognize indigenous groups within state borders as "peoples" with rights to self-determination and cultural survival.

Moreover, as other scholars have documented, the international indigenous rights movement of the last several decades has played a crucial role in influencing the actions of nation-states and their propensity to recognize indigenous rights. ${ }^{256}$ Thus, even purely domestic laws protecting indigenous rights - without any direct reference to international law-may, in fact, have been the products of international influence. ${ }^{257}$

The trend toward the domestic recognition of international indigenous rights is apparent, if nascent. As discussed at length in Part I.A., twenty countries, ${ }^{258}$ including virtually all Latin American countries with significant indigenous populations, have now ratified ILO Convention 169 concerning Indigenous and Tribal Peoples in Independent Countries. ${ }^{259}$ And 144 nationstates voted in favor of the U.N. General Assembly's adoption of the UNDRIP in 2007, with several of the abstentions and all of the four votes in opposition subsequently changing their position. As discussed elsewhere, regional bodies have also played a vital role in advancing indigenous rights at the domestic level. ${ }^{260}$

253. See ANAYA, supra note 1, at 114-15.

254. As Helfer and Slaughter point out, the Commission received over 6,600 petitions from 1997 until 2005, and the rate of submissions was rising; the nature of the Commission's work means that it "does much of the heavy judicial lifting for the Inter-American human rights system." Helfer \& Slaughter, supra note 134, at 924.

255. See, e.g., Ryan Goodman \& Derek Jinks, Incomplete Internationalization and Compliance with Human Rights Law, 19 EUR. J. INT’L L. 725, 726 (2008) (describing process of "acculturation"); see also GOODMAN \& JiNKS, supra note 30, at 21-37 (distinguishing "material inducement," "persuasion," and "acculturation”).

256. See Siegfried Wiessner, Re-Enchanting the World: Indigenous Peoples' Rights as Essential Parts of a Holistic Human Rights Regime, 15 UCLA J. INT’L L. \& FoR. AfF. 239, 282 (2010).

257. Id. at 283-84.

258. Convention No. 169, INTERNATIONAL LABOUR ORGANIZATION, http://www.ilo.org /indigenous/Conventions/no169/lang--en/index.htm (last visited Nov. 10, 2013).

259. See Xanthaki, supra note 238, at 29.

260. See id. at 32-34 (discussing the Inter-American system and the African system). 
Despite these and other advancements, however, critical questions remain about the implementation of indigenous peoples' rights into domestic law. ${ }^{261}$ Though relatively few, there are important examples. In 2007, for example, Bolivia became the first nation to expressly incorporate UNDRIP into domestic law. ${ }^{262}$ In 2008, Japan recognized the Ainu as indigenous people and directly cited UNDRIP in the resolution. ${ }^{263}$

Less directly, some states have recognized indigenous rights in actions that, albeit without citation to international law, hint at emerging global norms. For example, numerous national constitutions contain protections for indigenous peoples' rights. The constitutions of Bolivia, Brazil, Nicaragua, and Ecuador, among others, articulate protections for indigenous peoples that align with those set forth in ILO 169 and/or UNDRIP, even if they do not expressly reference those instruments. ${ }^{264}$

In 2007, the Supreme Court of Belize became the first national high court to cite the UNDRIP. ${ }^{265}$ In Aurelio Cal et al. v. Belize, the claimants sought redress for the government's failures "to recognize, protect and respect their customary land rights" based on "the traditional land use and occupation of the Maya people." ${ }^{266}$ In short, they argued that indigenous land rights constitute legitimate property rights in Belize. In ruling for the Maya, the Court cited to sources including Belize's own constitution, opinions of regional human rights systems, and the UNDRIP. ${ }^{267}$ The Court acknowledged that because the UNDRIP is a declaration, and because Belize had not ratified ILO 169, both documents comprised, at most, nonbinding instruments of customary international law. ${ }^{268}$ Yet, "where these resolutions or Declarations contain principles of general international law," the Court wrote, "states are not expected to disregard them." ${ }^{269}$ In sum, the Court found that the defendants were bound by domestic and international law "to respect the rights to and interests of the claimants as members of the indigenous Maya community.”270

261. See ANAYA, supra note 1, at 114 .

262. LEY No. 3760 DE 7 DE NOVIEMBRE DE 2007 (Bol.).

263. Rodolfo Stavenhagen, Making the Declaration on the Rights of Indigenous Peoples Work: The Challenge Ahead, in Reflections on UNDRIP, supra note 25, at 154.

264. See, e.g., CONSTITUCIÓN DE 2009 (Bol.); see also ANAYA, supra note 1, at 114-15. In another example, the Philippines passed human rights legislation in the Indigenous Peoples' Rights Act of 1997, Rep. Act No. 8371 (Oct. 29, 1997), available at http://www.gov.ph/1997/10/29/republic -act-no-8371.

265. Aurelio Cal v. Belize, Supreme Court of Belize (Claims No. 171 and 172 of 2007) (Oct. 18, 2007).

266. Id. 92.

267. Id. ๆ 131.

268. Id. १ศ 130-31.

269. Id. ๆ 131.

270. Id. ๆ 134. 
In other nation-states, recent judicial decisions reflect similar indigenous rights principles. ${ }^{271}$ In 2004, the South African Constitutional Court ruled that South African law recognized traditional land tenure systems and land rights of indigenous communities. ${ }^{272}$ In 2006, the Botswana High Court acknowledged the land rights of San hunter-gatherers, relying on principles that map onto those embodied in the UNDRIP, though full and fair implementation of the decision has not been realized. ${ }^{273}$ In 2013, the Constitutional Court of Indonesia held that the state could no longer assert ownership of "customary" forests ${ }^{274}$ because the forests were "located in the territories of indigenous people" and therefore "were part of indigenous rights."275 Despite real challenges to implementation of these decisions, there is hope that national courts will continue to draw on international principles when adjudicating indigenous rights. $^{276}$

In addition to these legislative matters and judicial decisions, the executive branches of numerous states have invited the Special Rapporteur on the Rights of Indigenous Peoples to conduct on-site visits and to investigate and report on the situation of indigenous peoples living within a state's borders. ${ }^{277}$ These visits can only occur with the consent and cooperation of the national governments, thereby engaging the state in the review of its treatment of indigenous peoples. ${ }^{278}$ In recent years, the Rapporteur has visited Botswana, Brazil, Nepal, the United States, Canada, and dozens of other countries, resulting in the development of a major body of U.N. reports on indigenous peoples' circumstances vis-à-vis international standards and state treatment

271. See Mabo v. Queensland (No. 2) (1992) 175 C.L.R. 1, 1-2 (recognizing Australian aboriginal land rights pursuant to native conceptions of land ownership and title).

272. Alexkor Ltd. v. Richtersveld Cmnty. 2003 (5) SA 460 (CC) at 38-39, 50, available at http://www.saflii.org/za/cases/ZACC/2003/18.html.

273. See Xanthaki, supra note 238, at 34 (discussing Sesana \& ors v Attorney General (52/2002) [2006] BWHC 1); BUREAU OF DEMOCRACY, HUMAN RIGHTS, AND LABOR, U.S. DEP'T OF STATE, 2009 HUMAN RIGHTS REPORT: BOTSWANA (2010), available at http://www.state.gov/j/drl /rls/hrrpt/2009/af/135939.htm (criticizing the government's lackluster implementation of the ruling).

274. See Nadya Natahadibrata, Government Recognizes Customary Forests, JAKARTA POST, May 18, 2013, at 1, available at http://www.thejakartapost.com/news/2013/05/18/government -recognizes-customary-forests.html.

275. See Abdon Nababan, Govt Urged to Resolve Problems with Indigenous People, JAKARTA Post, May 28, 2013, at 2, available at http://www.thejakartapost.com/news/2013/05/28/govt-urged -resolve-problems-with-indigenous-people.html.

276. See Xanthaki, supra note 238, at 34.

277. See Country Reports, JAMES ANAYA: UnITED NATIONS SPECIAL RAPPORTEUR ON THE RIGHTS OF INDIGENOUS PEOPLES, http://unsr.jamesanaya.org/list/country-reports (last visited Nov. 10, 2013).

278. See Statement by Professor S. James Anaya, Special Rapporteur on the Situation of Human Rights and Fundamental Freedoms of Indigenous Peoples, 8th Sess. U.N. Permanent Forum on Indigenous Issues, New York, May 20, 2009, page 5, available at http://unsr.jamesanaya.org /statements/statement-of-special-rapporteur-to-un-permanent-forum-on-indigenous-issues-2009. 
across the globe. ${ }^{279}$ And numerous states have long participated in the U.N. Human Rights Committee's general reporting procedures.

As for the United States, the State Department has indicated that while the UNDRIP is non-binding, it has "moral and political force." 280 The State Department's approach has been to identify the programs of the United States that it believes already comply with standards articulated in the UNDRIP (rather than outlining areas for reform), ${ }^{281}$ including federal-tribal “consultation," "redress" for property losses in the federal courts, and funding and technical support for economic development and health care. ${ }^{282}$ In March 2013, the Advisory Council on Historic Preservation, which oversees many indigenous sacred sites, expressed its support for the UNDRIP and announced specific plans to bring its activities into compliance. ${ }^{283}$ While no federal or state court in the United States has yet relied on the UNDRIP in any decision, many party briefs have cited it as reflective of global principles of indigenous human rights law. ${ }^{284}$ Perhaps exemplifying jurisgenesis via acculturation, the State Department has emphasized, "the United States is committed to serving as a model in the international community in promoting and protecting the collective rights of indigenous peoples as well as the human rights of all individuals."285

Without doubt, domestic implementation of indigenous peoples' human rights law around the globe is only beginning and faces serious challenges. But jurisgenesis is present and observable. Increased commitment to indigenous rights in domestic constitutions, court decisions, and legislation-and now the basis for a global protest movement-provide grounds for optimism around meaningful implementation of indigenous human rights law across the range of coercive, persuasive, and acculturative activities. ${ }^{286}$

279. See Country Reports, supra note 277.

280. U.S. DeP'T OF StATE, ANNOUNCEMENT OF U.S. SUPPORT FOR THE UNITED NATIONS DECLARATION ON THE RIGHTS OF INDIGENOUS PEOPLES 1, available at http://www.state.gov /documents/organization/184099.pdf (last visited Nov. 5, 2013) [hereinafter ANNOUNCEMENT OF U.S. SUPPORT FOR UNDRIP].

281. See generally id.

282. See generally id.

283. See Rob Capriccioso, Federal Agency Supports UNDRIP: A New Era in Tribal-Federal Relations?, INDIAN COUNTRY (June 3, 2013), http://indiancountrytodaymedianetwork.com/2013 /06/03/federal-agency-supports-undrip-new-era-tribal-federal-relations-149676.

284. Cf. Marrakush Soc. v. N.J. State Police, No. 09-2518 (JBS), 2009 WL 2366132, at *6 n.17 (D.N.J. July 30, 2009) (noting that UNDRIP is a declaration and not a binding instrument).

285. ANNOUNCEMENT OF U.S. SUPPORT FOR UNDRIP, supra note 280, at 2.

286. See Setting the Standard: Domestic Policy Implications of the UN Declaration on the Rights of Indigenous Peoples, Hearing Before the S. Comm. on Indian Affairs, 112th Cong. (2011); Idle No More: Stop the Harper Government's Attack on Indigenous Canadians, GLOBAL RESEARCH (Feb. 17, 2013), http://www.globalresearch.ca/idle-no-more-stop-the-harper-governments-attack-on -indigenous-canadians/5323274 (invoking the UNDRIP in indigenous protest movement of 20122013).

Going forward, even where international human rights law is implemented in states—and for that matter, tribes - there will remain important empirical questions about whether and to what extent legal 


\section{Human Rights in Indigenous Legal Systems}

This Section considers the influence of international human rights law and indigenous legal norms on one another, especially in lawmaking and advocacy by tribal nations and other indigenous governments. We focus on "indigenous legal systems," by which we mean internal lawmaking and governance of indigenous communities themselves.

Indigenous peoples have always had their own systems of law. ${ }^{287}$ Though too often those systems of law have been disregarded or suppressed by colonizing nations, today indigenous self-governance is ascending in many communities. Indian tribes in the United States retain inherent but limited rights of self-governance over their reservation lands and tribal members and exercise these through various forms of tribal government. ${ }^{288}$ In Canada, while national law significantly circumscribed First Nations' self-governance rights in the 1800s, there have been new opportunities for indigenous self-governance, including the creation of Nunavut, a self-governing territory. ${ }^{289}$ In Latin America, several national constitutions recognize some degree of indigenous territorial autonomy. ${ }^{290}$ In Panama and Colombia, for example, some indigenous communities maintain collectively-owned land bases, governed by indigenous councils according to traditional customary practices. ${ }^{291}$

During this contemporary resurgence in indigenous self-governance, ${ }^{292}$ and as part of the continuation of tribal lawmaking since time immemorial,

changes improve living conditions for indigenous peoples. To that end, empirical work about the situation of indigenous peoples in states around the world, including the Human Rights Council's Periodic Review, the Special Rapporteur's Country Reports, and the Permanent Forum's studies will all be critically important assessment tools. See ANAYA, supra note 1, at 105-09.

287. See, e.g., MattheW L.M. Fletcher, AMERICAN Indian Tribal LaW 67-84 (2011) (surveying the history of tribal governments and tribal justice systems).

288. See Riley, Governance, supra note 18.

289. See Thomas J Courchene, Aboriginal Self-Government in Canada, in PAPERS ON PARLIAMENT No. 21-PARLIAMENT AND THE CONSTITUTION: SOME ISSUES OF INTEREST 6 (1993), available at http://www.aph.gov.au/binaries/senate/pubs/pops/pop21/c03.pdf (noting that Nunavut relies on a public governance model not limited to Native people).

290. See, e.g., Willem Assies, Two Steps Forward, One Step Back: Indigenous Peoples and Autonomies in Latin America, in Autonomy, Self-GovernanCE AND CONFLICT ReSOLUTION: INNOVATIVE APPROACHES TO INSTITUTIONAL DESIGN IN DIVIDED SOCIETIES 180, 186 (Marc Weller \& Stefan Wolff eds., 2005). For a broader study of the recognition of indigenous rights and interests in Latin American constitutions, see Gonzalo Aguilar et al., The Constitutional Recognition of Indigenous Peoples in Latin America, 2 PACE INT'L L. ReV. ONLINE COMPANION 44 (2010), http://digitalcommons.pace.edu/cgi/viewcontent.cgi?article=1017\&context=pilronline.

291. See Assies, supra note 290, at 186-89.

292. For popular media accounts, see, for example, David Akin, The Successes and Failures for Self-Governance for Canada's First Nations, TORONTO Sun (Jan. 25, 2013), http://www. torontosun.com/2013/01/24/the-successes-and-failures-of-self-governance (surveying self-governance across several First Nations in Canada); Mark Betancourt, Guaraní People vs. Repsol: The Importance of Indigenous Self-Determination, FIRST PEOPLES WORLDWIDE (May 8, 2013), http://firstpeoples.org /wp/guarani-people-vs-repsol-the-importance-of-indigenous-self-determination (describing challenges of self-government experienced by the Guaraní people in Bolivia and certain initiatives to enhance traditional and contemporary self-governance among indigenous peoples). 
indigenous peoples have proven remarkably adept at incorporating law and practices from other sources, while attempting to keep true to indigenous values. $^{293}$ In some instances, indigenous peoples, through their governments and other institutions, are turning to international sources, along with their own tribal norms, to illuminate and ensure human rights for their own people.

We see two interrelated dynamics occurring when indigenous legal systems engage with international human rights law. First, we see the diffusion of international human rights norms in indigenous communities. Second, and perhaps even more powerfully, we also see the recovery and revitalization of indigenous peoples’ own human rights norms.

\section{A Brief Survey of Indigenous Engagement with International Human Rights Law: International and Indigenous Norms}

After the U.N. General Assembly adopted the UNDRIP in 2007, indigenous peoples around the world followed suit. In Canada, the Assembly of First Nations endorsed the UNDRIP in $2007 .{ }^{294}$ In the United States, tribal nations such as the Pit River Tribe and Gila River Tribe, among others, have done the same. ${ }^{295}$ More broadly, tribal governments have drawn on the principles and pronouncements of other human rights instruments, U.N. bodies, and international human rights systems in creating laws at the tribal level. We have uncovered several examples to demonstrate this phenomenon, including tribal constitutions and codes manifesting human rights language. ${ }^{296}$ Below we

293. Throughout history, there have often been jurisgenerative moments when European and indigenous laws have come into contact. See, e.g., Wolfgang J. Mommsen, Introduction to EUROPEAN EXPANSION AND LAW: THE ENCOUNTER OF EUROPEAN AND INDIGENOUS LAW IN 19TH- AND 20THCEnTURY AFriCA AND ASIA 1, 5-6, 11-13 (W.J. Mommsen \& J.A. de Moor eds., 1992). More contemporarily, American Indians in the United States have engaged in jurisgenerative lawmaking when they interpret federal laws, such as the Indian Civil Rights Act. See Mark D. Rosen, Evaluating Tribal Courts' Interpretations of the Indian Civil Rights Act, in THE INDIAN CIVIL RIGHTS ACT AT FORTY, supra note 18, at 275 (surveying the jurisprudence of tribal courts as authoritative interpreters of ICRA). While these points overlap somewhat with our project here, our focus is on the jurisgenerative process with respect to indigenous human rights in indigenous, domestic, and international forums.

294. See Implementing the UNDRIP, ASSEMBLY OF FIRST NATIONS, http://www.afn.ca/index .php/en/policy-areas/implementing-the-Undrip (last visited Nov. 10, 2013).

295. See Marc Dadigan, Pit River Tribe Endorses UNDRIP, INDIAN COUNTRY (Apr. 10, 2012) (explaining that the Pit River Tribe, Gila River Tribe, and Seminole Tribe have all voted to endorse the UNDRIP); $c f$. A Resolution Applauding the United States Government for Endorsing the United Nations Declaration of the Rights of Indigenous Peoples, COUNCIL OF THE CHEROKEE NATION, No. R-06-11 (Dec. 3, 2011), available at https://cherokee.legistar.com/Legislation.aspx (change the search year to "2011"; search for "R-06-11").

296. See, e.g., LiTtLE TRAVERSE BAy BANDS OF ODAWA CONST. art. VI (2005), available at http:/www.narf.org/nill/Codes/ltraverse/t1.pdf ("We, the Little Traverse Bay Bands of Odawa Indians, speak through this document to assert that we are a distinct nation of Anishinaabek of North America that possess the right to: self-determination; freely determine our political status; freely pursue our economic, social, religious and cultural development, and determine our membership, without external interference. These same rights and principles the Little Traverse Bay Bands of Odawa Indians acknowledge to be inherent among other peoples, nations and governments throughout the world. We 
describe several tribal court opinions relying on international law and the creation of human rights bodies within tribal communities that are designed to specifically deal with indigenous peoples' human rights concerns. As we note above, these examples reveal both the diffusion of international norms as well as the recovery of indigenous norms.

Galit Sarfaty's work highlights the experience of the Pimicikamak Cree Nation in Canada, which incorporated international human rights law into tribal governance. She points to the case as an example of "international norm diffusion" and the process of "mediation” among local, state, and international law. ${ }^{297}$ The Pimicikamak Cree occupy a reserve north of Winnipeg where they have long enjoyed a subsistence lifestyle, operated by consensus style government, and have spoken Cree as the language of the community. With the benefit of a 1995 law permitting self-government agreements, the Cree began to reformulate their internal governing systems. They deliberately chose at that time to draw from their own traditional law, as well as Canadian and international law. According to Sarfaty, the Cree had learned about international human rights law largely through their campaign to expose violations of their rights by Canada and hydroelectric companies in the 1980s and 1990s, through advocacy to the United Nations and other international bodies. As Sarfaty puts it, "Having been exposed to international human rights norms through their political mobilization, the Cree began to incorporate these norms into both their official discourse (e.g., their constitution, laws, and formal statements to external parties) and their local political discourse.”298

In the process of developing "modern governance" within the framework of their "[t]raditional ways," 299 the Cree first revived and updated traditional institutions, such as their consensus-based dispute resolution format and its reliance on the values of min-oo-puh-now (harmony), mi-nah-sin (beauty), and mi-nah-yaw-win (well-being). ${ }^{300}$ At the same time, they kept and improved upon certain of the Indian Act's institutions, including the appointment of a Chief and Council. Perhaps most remarkably, the Cree restructured their law to ensure that it recognized individual and collective rights of the community, with particular attention to the rights of women and youth. ${ }^{301}$ Accordingly, the

recognize their sovereignty and pledge to maintain relations with those peoples, nations and governments who acknowledge those same fundamental human rights and principles, and who recognize the sovereignty of the Little Traverse Bay Bands of Odawa Indians.”); NORTHERN ARAPAHO CODE, 7 N.A.C. § 401 (2004), available at http:/www.northernarapaho.com/sites /northernarapaho.com/files/NA Code Title 7 Peacemaker 11-4-04.pdf (describing grounds for an order terminating peacemaking process as "[c]onduct by the Peacemaker in the peacemaking process which is degrading, inhuman, dangerous, assaultive or otherwise violative of basic human rights”).

297. See Galit A. Sarfaty, International Norm Diffusion in the Pimicikamak Cree Nation: A Model of Legal Mediation, 48 HARV. INT'L L. J. 441, 442-45 (2007).

298. Id. at 474.

299. Id. at 472 .

300. Id. at 471 .

301. Id. at 475 . 
"First Written Law" transferred legislative power from the Council of Elders to a new Women's Council and Youth Council. ${ }^{302}$ Notably, the Cree also expressly referenced the ICCPR and ICESR, the Canadian Charter, and Cree law in their new constitution.

Per Sarfaty's account, the Cree appear to have been at the forefront of integrating tribal with international legal sources, moving toward a revitalized indigenous government that is responsive to contemporary circumstances. According to the Assembly of First Nations, the Cree now have "a model of accountable governance based on inherent jurisdiction that seeks to reconcile tradition with modern circumstances.”303

American Indian tribes too have participated in the revitalization of tribal government, with attention to the need to address vestiges of colonialism, including the federal government's use of tribal institutions as agents of assimilation. For example, today's tribal courts have authority over certain civil and criminal matters arising on reservations, as delineated in tribal statutory and common law. ${ }^{304}$ These courts, however, bring complicated histories to their work: some courts evolved directly from traditional tribal dispute resolution systems, while others were created by the federal government to adjudicate its special Indian regulatory law on reservations beginning in the $1880 \mathrm{~s}^{305}$ These courts of Indian offenses had the task of enforcing federal laws, including those that expressly forbade and punished the practice of Indian religions. ${ }^{306}$ Tribal courts have also been highly influenced by federal decisions and statutes that regulate their civil and criminal jurisdiction. ${ }^{307}$

With those legacies weighing heavily, today's tribal courts work toward being internally responsive to tribal needs and norms, as well as representing institutional legitimacy to outsiders, a set of challenges that has been aptly explored by Matthew Fletcher. ${ }^{308}$ One aspect of the struggle to decolonize tribal courts is to revitalize traditional customary law. For example, after years

302. Id. at $475-76$.

303. Id. at 470 (citing the Assembly of First Nations' description of the Pimicikamak Cree government).

304. See FLETCHER, supra note 287, at 67-92; Catherine T. Struve, Sovereign Litigants: Native American Nations in Court, 55 VILL. L. REV. 929, 934-35 (2010).

305. See FLETCHER, supra note 287, at 67-92; see also Matthew L.M. Fletcher, Toward a Theory of Intertribal and Intratribal Common Law, 43 HOUS. L. REV. 701 (2006).

306. See REPORT OF COMMISSIONER OF INDIAN AFFAIRS W.A. JONES, OCT. 16, 1902, reprinted in 2 WILCOMB E. WASHBURN, THE AMERICAN INDIAN AND THE UNITED STATES: A DOCUMENTARY HISTORY 726-27 (1973).

307. See DAVID H. GETCHES ET AL., CASES AND MATERIALS ON FEDERAL INDIAN LAW 40304, 447-531 (6th ed. 2011).

308. For a leading series of articles on these challenges, see Matthew L.M. Fletcher, Rethinking Customary Law in Tribal Court Jurisprudence, 13 MICH. J. RACE \& L. 57 (2007); Matthew L.M. Fletcher, The Supreme Court's Legal Culture War Against Tribal Law, 2 INTERCULTURAL HuM. RTS. L. REV. 93 (2007); Fletcher, supra note 305; Matthew L.M. Fletcher, Looking to the East: The Stories of Modern Indian People and the Development of Tribal Law, 5 SEATTLE J. FOR SOC. JUST. 1 (2006). 
of "borrowing" from neighboring state law to resolve disputes ranging from family to criminal law, the Navajo Nation Supreme Court has now expressed a jurisprudential preference for applying Navajo common law over federal and state sources of law. ${ }^{309}$ As Navajo Supreme Court Justice Ray Austin has explained, this process "involves retrieving ancient tribal values, customs, and norms and using them to solve contemporary legal issues." ${ }^{310}$ Writing from an Anishinaabe legal perspective, John Borrows describes the process of "drawing out law" that involves looking to indigenous experience for legal norms and processes. ${ }^{311}$ Here we observe that, in the jurisgenerative moment, tribal courts are also using international human rights law as a tool in decolonizing tribal court jurisprudence and emphasizing indigenous human rights norms.

In the case of Eastern Band of Cherokee Indians v. Torres, for example, the Supreme Court of the Eastern Band of Cherokee Indians relied in part on international legal norms to contain the impact of Oliphant v. Suquamish Tribe, a 1978 U.S. Supreme Court decision that severely limits tribes' ability to prosecute non-Indians for crimes committed on reservations. ${ }^{312}$ Deciding that Oliphant did not prevent the court from hearing a case against a non-Indian, non-citizen of the United States, the Torres decision drew on tribal and international law. ${ }^{313}$ First, the Court looked at the Cherokee Code which acknowledged that "[t]he Judicial Branch shall not have jurisdiction over matters in which the exercise of jurisdiction has been specifically prohibited by a binding decision of the United States Supreme Court, the United States Court of Appeals or by an Act of Congress." ${ }^{314}$ A thorough review of these sources, including Oliphant, revealed that the tribe's jurisdiction had not been abrogated with respect to asserting criminal jurisdiction over non-Indians who are not U.S. citizens. As the court wrote, "The Cherokee Nation had such jurisdiction in 1492; it has it today." ${ }^{315}$ Preserving this jurisdiction was important, according to the court, "to protect the safety, health, economic development, liberty, and the general welfare of the Eastern Band ... and all other people

309. See, e.g., In re Validation of Marriage of Francisco, 6 Navajo Rptr. 134, 135-36 (1989) (ruling according to Navajo law, rejecting "outside law”).

310. See Austin, supra note 23, at xvii (describing this process as "a lesson embedded in the Navajo Creation Scripture and Journey Narratives," in which the Navajo's oral stories teach humans about how to acquire knowledge, relate to one another, and adapt to their circumstances).

311. See generally JOHN BORROWS, DRAWING OUT LAW: A SPIRIT's GUIDE (2010).

312. Oliphant v. Suquamish Tribe, 435 U.S. 191 (1978). Beyond the Torres case, the EBIC Tribal Courts have been engaged in a process of decolonizing their jurisprudence. See J. Matthew Martin, The Nature and Extent of the Exercise of Criminal Jurisdiction by the Cherokee Supreme Court: 1823-1835, 32 N.C. CENT. L. REV. 27 (2009); J. Matthew Martin, Federal Malpractice in Indian Country and the "Law of the Place": A Re-Examination of Williams v. United States Under Existing Law of the Eastern Band of Cherokee Indians, 29 CAMPBELL L. REV. 483 (2007).

313. Eastern Band of Cherokee Indians v. Torres, 2005 N.C. Cherokee Sup. Ct. LEXIS 6.

314. See id. at *5 (citing CHEROKEE CODE § 7-2(a) (2001)).

315. Id. at *6; see also id. at *7-8 (Philo, J.) (concurring) (providing a spirited exposition of the discriminatory quality of federal laws that limit tribal court jurisdiction over non-Indians). 
who live, work or visit on Tribal lands. ${ }^{316}$ In addition, the court noted that its holding, "and the federal policy of self-determination of Indian tribes, is consistent with and supported by established norms of customary international law," including anti-discrimination principles, as well as "the traditions, customs and culture of the Eastern Band of Cherokee Indians." "317

In another case, Selena v. Hualapai Tribe, the Hualapai Court of Appeals considered arguments that, by allowing a child's parent to participate in court proceedings, the trial court had improperly handled the testimony of a child witness leading to the defendant's criminal conviction in a matter involving sexual assault. ${ }^{318}$ The appellate court noted the challenge of preserving the well-being of a ten-year-old child who had expressed fear at facing the defendant in court, while at the same time preserving the defendant's constitutional rights. ${ }^{319}$ In resolving the question, the court relied on the Hualapai Law \& Order Code's choice-of-law provision, which allows the Hualapai courts to "look to other legal systems for guidance where Hualapai written or common law does not cover the matter in question." 320 Thus, the appellate court set up the jurisgenerative moment by first establishing its ability to look to extraterritorial law for guidance when Hualapai laws are silent. The Court ultimately borrowed from the International Criminal Court Rules, which more leniently allow for the presence of a "support person" during proceedings for child witnesses. ${ }^{321}$

These cases provide an anecdotal glimpse into how tribal courts are interpreting and revitalizing tribal law through the lens of international law to better serve the needs of the reservation polity.

\section{The Recovery and Revitalization of Indigenous Human Rights in Two Communities: The Navajo Nation and Eastern Band of Cherokee Indians}

In this Section, we describe how two U.S. Indian Tribes-the Navajo Nation and the Eastern Band of Cherokee Indians—are engaging, developing,

316. Id. at *6.

317. Id. at *7 (citing The Paquete Habana, 175 U.S. 677 (1990); International Convention on the Elimination of All Forms of Racial Discrimination; and other sources). In this regard, the tribal court opinion implicitly took a position in the debate on whether customary international law is a source of federal law. See Ryan Goodman \& Derek P. Jinks, Filartiga’s Firm Footing: International Human Rights and Federal Common Law, 66 FoRDHAM L. REV. 463 (1997) (arguing for customary law as an aspect of federal law). But see Curtis A. Bradley \& Jack L. Goldsmith, III, The Current Illegitimacy of International Human Rights Litigation, 66 FORDHAM L. REV. 319 (1997) (arguing against Goodman and Jinks's position); Curtis A. Bradley \& Jack L. Goldsmith, Customary International Law as Federal Common Law: A Critique of the Modern Position, 110 HARV. L. REV. 815 (1997).

318. See Selana v. Hualapai Tribe, No. 2008-AP-005, HTC No. 2007-CR-282ABC (Hualapai Ct. App. Dec. 17, 2008).

319. See id.

320. Id. at 4 (citing Bender v. Hualapai Tribe, 2005-AP-011, 5 (Jul. 16, 2007)).

321. Id. at 5. 
and revitalizing human rights through a jurisgenerative process. This process embraces tribal and international sources in ways that portend change and growth in both indigenous and international advocacy. Here we identify and analyze examples that have not yet, to our knowledge, been discussed in the legal literature.

We observe that the experience of human rights emerging from the Navajo Nation, the Eastern Band of Cherokees, and other communities is not merely an example of "norm entrepreneurship"322 or "norm diffusion,",323 in which worldly activists bring new concepts to tribal communities. ${ }^{324}$ In these examples, we believe we are seeing something potentially more reciprocal, more vibrant, and, in fact, more indigenous. While tribes are certainly embracing international human rights concepts like "self-determination," as suggested in the Navajo example, they are simultaneously uncovering their own human rights norms. They are, in turn, applying these norms, in conjunction with other sources, to internal and external advocacy, as well as toward the goals of decolonization and revitalization, in tribal, domestic, and international forums alike.

\section{a. The Navajo Nation Human Rights Commission: Race Relations, Sacred Sites, and Water Rights}

The Navajo Nation is a federally recognized American Indian tribe that resides on a reservation of 27,425 square miles stretching across the states of New Mexico, Arizona, Utah, and Colorado. The Navajo Nation has 298,000 citizens, approximately 173,000 of whom live on the reservation, along with several thousand non-Navajo residents, including Anglos, Hopis, and others. The reservation is located within the treaty-guaranteed, traditional territory of the Navajo, among their four sacred mountains.

For decades, the Navajo Nation has been a leader in developing legal institutions and substantive law, with an express goal of imbuing contemporary practice with Navajo values and processes. ${ }^{325}$ The Navajo Nation operates a three-branch form of government, with popularly elected legislators and executives as well as an appointed judiciary. ${ }^{326}$ Navajo traditional or customary

322. See Harold Hongju Koh, The 1998 Frankel Lecture: Bringing International Law Home, 35 Hous. L. REV. 623, 646-47 (1998) (arguing that reliance on "norm entrepreneurs," including thought leaders who mobilize popular opinion, is one way to "bring international law home”).

323. See Sarfaty, supra note 297, at 443.

324. See id. at 441-42 (querying what happens when indigenous activists return home after trips to the U.N. in Geneva when they have "learned, employed, and even influenced international norms”).

325. See AUSTIN, supra note 23; see also Ezra Rosser, Displacing the Judiciary: Customary Law and the Threat of a Defensive Tribal Council: A Book Review of Raymond D. Austin, Navajo Courts and Navajo Common Law: A Tradition of Tribal Self-Governance (2009), 34 AM. INDIAN L. REV. 379 (2010).

326. See Sarah Krakoff, A Narrative of Sovereignty: Illuminating the Paradox of the Domestic Dependent Nation, 83 OR. L. REV. 1109, 1165-66 (2004). 
law, as well as the legislative code and judicial decisions are all vibrant aspects of Navajo governance. ${ }^{327}$ In 2006, the legislative council of the Navajo Nation created an entity broadly devoted to human rights - the Navajo Nation Human Rights Commission (NNHRC) — which is obligated to "address discriminatory actions against citizens of the Navajo Nation., ${ }^{328}$ Toward this end, the NNHRC receives complaints, conducts investigations, gathers information, and engages in advocacy work. It advocates for Navajo human rights, especially in areas of discrimination, sacred sites access, forced relocation, and unexplained deaths, through communication with the local, state, and federal governments, as well as with international human rights tribunals and organizations. ${ }^{329}$

The NNHRC takes a deeply integrative approach to human rights. In terms of substantive law, the NNHRC draws primarily from Navajo law, particularly the Diné principles of Sa'a Naaghai Bik'e Hozhoo, Hashkéejí, Hózhóójí and K'é: "being resilient, content, disciplined and maintaining peaceful relationships with all creation.” ${ }^{330}$ The Commission's work also relies on international law principles, even in some cases to critique the positive law within the Navajo Nation. Regarding self-determination, for example, the NNHRC draws on Articles 3 and 4 of the UNDRIP, which define selfdetermination as an attribute of indigenous peoplehood. ${ }^{331}$ It contrasts this with the Navajo Nation's own legislative code, which describes self-determination merely as a "goal,"332 and has, accordingly, called for legislative reform within the Navajo Nation to give greater strength to the Navajo Nation's own articulation of the term. ${ }^{333}$

This example crystallizes our understanding of how even internal Navajo Nation power brokers can be, and are, challenged by a distinctly tribal human rights commission that is fueled both by the Navajo cosmologies, as well as the force and persuasion of international human rights. This sits in direct contrast to the specter of the insulated, isolated paideic nomos that scholars had feared - one that serves to only reify power and speak to the viewpoints and rights of "cultural elites." ${ }^{\text {,34 }}$ We see this convergence of the UNDRIP with various sources of Navajo law as marking a distinctive, jurisgenerative moment, wherein the Navajo government is urged—oftentimes with the

327. See Austin, supra note 23, at $\mathrm{xx}$-xxi.

328. An Act Relating to Human Services, Economic Development, Judiciary, and Intergovernmental Relations; Approving the Navajo Nation Human Rights Commission, 2 N.N.C. $\S 921$ (2006), available at http://www.nnhrc.navajo-nsn.gov/docs/Oct2006RESOLUTION.pdf.

329. See Forced Relocation, NAVAJO NATION Human Rights COMMISSION, http://www .nnhrc.navajo-nsn.gov/forcedRelocation.html (last visited Nov. 10, 2013).

330. See NNHRC Mission/Vision, supra note 10.

331. See Self Determination, NAvajo NATION Human Rights Commission, http://www .nnhrc.navajo-nsn.gov/selfDetermination.html (last visited Nov. 10, 2013).

332. See id.

333. See id.

334. See Sunder, supra note 147, at 553; see also Resnik, supra note 24. 
conversation occurring, quite literally, in Navajo-to re-engage its own traditional, political vision.

The NNHRC's investigative and advocacy projects similarly reveal jurisgenerative trends. The NNHRC's initial project, involving the investigation of hate crimes against Navajo people occurring in border towns, integrated tribal, domestic, and international norms. The NNHRC's 2008-2009 report began with a recitation of Navajo values that had guided the NNHRC in taking victim assessment testimony from over 400 individuals. The report emphasized that speeches at council meetings must be guided by $k$ ' $e$, "the 'glue' that creates and binds relationships between people.” ${ }^{335}$ The report also indicated a reliance on UNDRIP's principles of equality, cultural difference, non-discrimination, and indigenous human rights ${ }^{336}$ in assessing the interconnected, deeply contextual problems of Navajo homelessness, loss of identity and culture, vulnerability to discrimination (including in consumer transactions, education, and employment), and violent crime.

The NNHRC has also addressed sacred sites protection, especially with respect to the infamous case of Navajo Nation v. U.S. Forest Service. ${ }^{337}$ In that case, the Ninth Circuit upheld the U.S. Forest Service's decision to permit the use of treated sewage effluent in San Francisco Peaks ski area snowmaking, which desecrated one of the Navajo people's holiest mountains, in the face of claims alleging violations of religious freedoms and environmental rights. ${ }^{338}$ Noting the losses experienced by tribal members when prevented from accessing sites to "conduct prayers, ceremonies and present offerings," an NNHRC report called on both the city of Flagstaff and the Navajo Nation itself to take a stronger stance to prioritize Navajo religion and culture over competing economic opportunities. ${ }^{339}$ The NNHRC's assessment drew on UNDRIP Articles 11 and 12, which guarantee indigenous peoples religious and cultural freedoms, with special protections for access to sacred sites. ${ }^{340}$ It also cited “Diné Fundamental Law, the Diné Bi Beehaz’áannii Bitsé Siléí, adopted and enacted as the primary law of the Navajo Nation in 2002,"341 which specifically identifies and protects the San Francisco Peaks as a "living mountain.”342

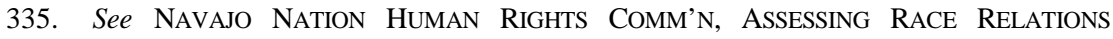
Between NavaJos and Non-NAVAJOS 2008-2009: A ReVIEW OF BORDER TOWN RACE RELATIONS, at ii (2010), http://www.nnhrc.navajo-nsn.gov/docs/NewsRptResolution/071810 Assessing Race Relations Between Navajos and Non-Navajos.pdf [hereinafter NNHRC, AsSESSING RACE RELATIONS].

336. Id.

337. Navajo Nation v. U.S. Forest Serv., 535 F.3d 1058 (9th Cir. 2008).

338. Id.

339. NNHRC, ASSESSING RACE RELATIONS, supra note 335, at xiii.

340. Id.

341. Id. at xiii n.3.

342. Id. at xiii n.4. 
The NNRHC took its claims a step further in 2010, submitting a formal complaint to the U.N. Special Rapporteur on Indigenous Peoples. ${ }^{343}$ The complaint alleged that the United States violated international law and the human rights of the Navajo people through its failure to protect the San Francisco Peaks. Invoking the language of international human rights discourse, the NNHRC Executive Director stated, “The Navajo people is a part of the world community and the world community has set standards for a good reason[.] . . . The United States must be responsible and abide by international standards that protect the human rights of Navajos." ${ }^{344}$ The Special Rapporteur, in turn, referenced the NNHRC's complaint about the San Francisco Peaks in his recent country report on the United States. ${ }^{345}$

In one of its most ambitious moves, the NNHRC opposed proposed federal legislation that would settle Navajo and Hopi claims to water rights on the Little Colorado River. The proposed legislation was supported by Navajo Nation President Ben Shelly, while the NNHRC's advocacy on this issue was perceived as representing "the people," especially grassroots groups. ${ }^{346}$ The NNHRC opposed the federal, state, and tribal governments, as well as arguably self-interested corporate players. According to the NNHRC, Navajo people were granted insufficient notice of and participation in the legislative process in violation of the UNDRIP's call for "free, prior and informed consent" by indigenous peoples to measures affecting their interests. ${ }^{347}$

Relying on UNDRIP's Article 26, the NNHRC report asserted that "[w]ater is a Navajo natural resource," belonging to "[i]ndigenous peoples."348 And, in this case, it belonged to the Diné people in particular. The NNHRC elaborated from Navajo tradition that water and other resources "are fundamental, sacred and spiritual sustenance to the Diné people since time immemorial," and are linked to religion, culture, sustenance, clan

343. See NNHRC Passes Legislation Requesting President Obama to Suspend Forest Service's Snowbowl Permit, NAVAJO-Hopi OBSERVER (Sept. 20, 2011), http://nhonews.com/Main .asp?SectionID=1\&SubSectionID=1\&ArticleID=13932.

344. Id. (quoting Leonard Gorman of the NNHRC).

345. Human Rights Council, Rep. of the Special Rapporteur on the Rights of Indigenous Peoples, James Anaya, on the Situation of Indigenous Peoples in the U.S., 21st Sess., U.N. Doc. A/HRC/21/47/Add.1 (Aug. 30, 2012), http://unsr.jamesanaya.org/docs/countries/2012-report-usa-a -hrc-21-47-add1_en.pdf.

346. See NAVAJO NATION Human Rights COMM’n, RESOLUTION OF THE NAVAJO NATION HUMAN RIGHTS COMMISSION (May 18, 2012), available at http://www.nnhrc.navajo-nsn.gov/docs /NewsRptResolution/Resolutions/NNHRCMAY-18-12.pdf [hereinafter NNHRC RESOLUTION].

347. Id. ๆ 8. The NNHRC Executive Director later softened allegations of FPIC violations by the Navajo Nation. See Press Release, Navajo Nations Human Rights Commission, Statement by the Navajo Nation Human Rights Commission Executive Director to Clarify Free, Prior and Informed Consent (Apr. 17, 2012), available at http://www.nnhrc.navajo-nsn.gov/PressReleases/2012/Apr /041712_Statement_by_NNHRCs_Executive_Director_to_clarify_Free,_Prior_and_Informed Consent.pdf.

348. See NNHRC RESOLUTION, supra note 346, ๆ 4. 
identifications, and Navajo ceremonies. ${ }^{349}$ As the NNHRC explained, "Water is in the Diné clans such as Tó 'áháni, Tábąąha, To’aheedlíinii, Tóhdich'íinii, Tótsohnii, Tó Baazhní'ázhi, to name a few." ${ }^{350}$ For the Diné, their peoples originated "around the four corners region which is the Diné female heart of the earth.”351

On May 18, 2012, the NNHRC adopted a resolution opposing the NavajoHopi Little Colorado River Water Rights Settlement Act of 2012 on grounds that it violated the human rights of the Diné people by denying them adequate participation in the water resource decision. ${ }^{352}$ The NNRHC called for all elected officials to oppose the measure as well. On July 5, 2012, the Navajo Nation Council voted 15-6 against the settlement and federal enabling legislation. $^{353}$

The work of the NNHRC illustrates the jurisgenerative moment in indigenous peoples' human rights. The NNHRC thus far has embraced a capacious set of claims and has drawn fluidly from multiple sources of law to define human rights for the Dine people. Notably, the NNHRC does not seem to struggle over some of the dichotomous categories, such as individual and tribal rights, that so fixate many commentators. Its complaint process allows for the investigation of human rights violations by a number of possible parties, including police, courts, and schools, both within and outside the Navajo Nation. ${ }^{354}$ In all of its endeavors, the NNHRC has advanced the concept and practice of human rights in ways that draw from both Navajo and international law, exhibiting growth and reflecting indigenous values in the law-making process.

\section{b. The Eastern Band of Cherokee Indians: Responding to Violence Against Women}

The Eastern Band of Cherokee Indians (the "Eastern Band” or "Eastern Cherokee”), primarily located on the Qualla Boundary in North Carolina, is a tribe of over 13,000 members, of whom approximately 9,000 reside on tribal land. ${ }^{355}$ The Eastern Band's government operates pursuant to a tribal charter

349. Id. ๆ 5.

350. Id.

351. Id.

352. See generally id.

353. See Felicia Fonseca, Navajo Council Rejects Water Rights Settlement, AZCENTRAL.COM (July 6, 2012), http://www.azcentral.com/news/20120705PNI0706-wir-arizona-navajo-water-rights -settlement-rejected.html.

354. See Complaint Form, Navajo Nation Human Rights Commission, available at http://www.nnhrc.navajo-nsn.gov/docs/Forms/NNHRC_Complaint_Form_NNHRC_Release _Form.pdf (last visited Nov. 6, 2013).

355. See generally JoHn R. Finger, CHEROKEe AMERICANS: THE EASTERn BAND OF CHEROKEES IN THE TWENTIETH CENTURY (1991) (providing more information on the community). 
and code and has an elected council and principal chief, as well as a separate judiciary. ${ }^{356}$

In 2011, the Eastern Band hosted United Nations Special Rapporteur on Violence Against Women, Rashida Manjoo, during her country visit to the United States. ${ }^{357}$ Manjoo's visit occurred during a period of unprecedented national and global attention on the issue of American Indian women's safety and justice. According to Congressional findings, 34 percent of American Indian and Alaska Native women will be raped in their lifetimes, and 39 percent of them will be subject to domestic violence. ${ }^{358}$ These rates exceed those experienced by any other population of women in the United States. ${ }^{359}$ The experience of the Eastern Cherokees in combating these problems suggests a role for international human rights law in empowering indigenous women to recover and revitalize norms protecting women in contemporary circumstances, and to seek reform at the tribal, national, and international levels.

The causes of violence against American Indian women are complex and numerous. ${ }^{360}$ Scholars generally agree that many indigenous societies, such as the Eastern Cherokee, had historical legal and societal mechanisms to protect women from sexual assault and other forms of violence. ${ }^{361}$ Yet, the social, economic, and cultural upheaval experienced by indigenous peoples during generations of European conquest and colonization severely undermined the health and well-being of indigenous communities; and as indigenous communities suffered, indigenous women became more vulnerable to violence. ${ }^{362}$

Observers have argued that the Cherokees' matrilineal and matrilocal social organization and traditional respect for Cherokee women's autonomy

356. See CHEROKEE CODE (2010), available at http://narf.org/nill/Codes/ebcicode.

357. See Human Rights Council, Report of the Special Rapporteur on Violence Against Women, Its Causes and Consequences, Ms. Rashida Manjoo: Mission to the United States of America, 17th Sess., U.N. Doc. A/HRC/17/26/Add.5 (June 6, 2011) [hereinafter Report of Special Rapporteur Manjoo].

358. Tribal Law and Order Act of 2010, Pub. L. No. 111-211, § 201(a)(5), 124 Stat. 2261, 2262-63.

359. Id.

360. See Sarah Deer, Toward an Indigenous Jurisprudence of Rape, 14 KAN. J.L. \& PUB. POL'Y 121, 123 (2004) (discussing causes of sexual violence in Indian country).

361. See, e.g., Sarah Deer, Sovereignty of the Soul: Exploring the Intersection of Rape Law Reform and Federal Indian Law, 38 SUFFOLK UNIV. L. REV. 455, 460 (2005) (“Our histories and oral teachings reveal the effectiveness of these [traditional] justice systems.”).

362. See Deer, supra note 360, at 123 n.21; see also Larissa Behrendt, Consent in a (Neo) Colonial Society: Aboriginal Women as Sexual and Legal 'Other,' 15 AUSTL. FEMINIST STUD. 353 (2000); Hannah S. Scott \& Rebecca L. Beaman, Sexual Assault Among Aboriginal and NonAboriginal Peoples in a Western Canadian City: A Case for Including Race When Collecting Crime Data, 1 ONLINE J. JUST. STUD., Jan. 2003, http://ojjs.uoit.ca/JOURNAL/backissues/ojjs/html/issues /1.1/scott-beaman.html. See generally SHARING OUR STORIES OF SURVIVAL: NATIVE WOMEN SURVIVING VIOLENCE (Sarah Deer et al. eds., 2008). 
historically served to protect women and children from abuse. ${ }^{363}$ Pre-contact Cherokee communities were structured around clan identities and kinship obligations, inherited from one's mother, as well as local town political organization. $^{364}$ Women controlled the fields and homes, chose their own sexual partners, and could divorce them with little disruption. ${ }^{365}$ Men, in turn, were responsible for hunting, warfare, and political activities that often kept them away from home. These gender roles were reflected in Cherokee oral stories, which described balance between female and male figures and modeled the peaceful resolution of disputes between spouses. ${ }^{366}$ Yet, the traditional law of the Cherokees also provided sanctions for assault and rape, ${ }^{367}$ and if a husband or partner killed his wife, her clan was obligated to seek retribution from his. ${ }^{368}$

The cosmology, socioeconomic structure, and dispute resolution systems of the Cherokees, then, offered protections for women. ${ }^{369}$ But in the eighteenth and nineteenth centuries, contact with European governments (and eventually the federal and state governments of the United States) and other nonCherokees created pressure to consider new forms of government, religion, and dispute resolution. ${ }^{370}$ With the ascension of a national governing council, the abolition of clan law, and new legislation providing for the transmission of citizenship and property along male (as well as female) family lines, some of the traditional protections for women dissipated. ${ }^{371}$ Increasingly violent incursions of white settlers, the reduction of the Cherokee land base, introduction of alcohol, religious conversion, and usurpation of tribal jurisdiction by surrounding states all made it difficult to address social issues through traditional Cherokee norms and structures. ${ }^{372}$ At various points, federal

363. See ThedA Perdue, CHEROKEe Women: Gender AND Culture ChANGe, 1700-1835, at 45 (1999).

364. See id. at 42, 94.

365. See CAROLYN Ross JohnSTON, CHEROKEe WOMEN IN CRISIS: TraIL OF TEARS, CiviL WAR, AND ALLOTMENT, 1838-1907, at 14 (2003).

366. See, e.g., Kana'tí and Selu: Origin of Game and Corn, in JAMES MoONEY, MYTHS OF THE CHEROKEE 242 (1995); Origin of Strawberries, in MOONEY, supra, at 259.

367. See RENNARD StRICKLAND, Fire AND tHe SPIRITS: CHEROKEe LAW FROM Clan to COURT 34-39 (1975) (describing sanctions for deviations in spiritual, community, clan, and individual conduct).

368. See, e.g., PERDUE, supra note 363, at 50, 52.

369. See id. at 40-57; see also TiYa Miles, Ties That Bind: The Story of AN AfroCHEROKEE FAMILY IN SLAVERY AND FREEDOM 50-51 (2005) (describing the vulnerability of slave women who lacked a Cherokee clan for protection).

370. See Theda Perdue, From Clan to Court: Another Look at the Early Cherokee Republic, 24 AM. INDIAN Q. 562 (2000); see also PERDUE, supra note 363, at 56.

371. See PERDUE, supra note 363, at 140-58 (noting nineteenth century changes to Cherokee governance, property, citizenship, and homicide and their impacts on Cherokee women and society).

372. See, e.g., id. at 178-79 (describing ways in which missionaries would "break down Cherokee family structure" and the contribution of alcohol abuse to violence against Cherokee

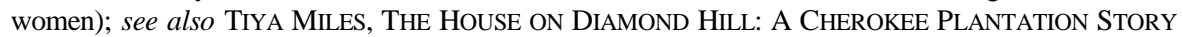


policy makers and churches sought to elevate Cherokee women's “equality” by encouraging them to take on European gender roles, such as weaving and sewing, and leave farming for the men. ${ }^{373}$ At the tribal level, new statutes codified the rights of married women to own property. ${ }^{374}$ Notwithstanding the "cultural persistence" of Cherokee women, ${ }^{375}$ however, scholars have argued that the de-stabilization of gender, labor, and cultural norms disrupted the matrilineality of Cherokee society ${ }^{376}$ and may have left women more vulnerable to domestic violence at key points in the Removal, Civil War, and Allotment eras. ${ }^{377}$ Other commentators have reported on the contrast between contemporary episodes of violence-compounded by the political, economic and social legacies of federal policies in Indian Country - and what they describe as the Cherokee "Harmony Ethic.,"378

In Cherokee communities, as elsewhere in Indian Country, contemporary rates of rape and domestic violence suffered by Native women suggest a breakdown, among other things, of traditional indigenous values and clan structures, caused by conquest and colonization. ${ }^{379}$ In the United States, addressing these issues through tribal justice systems has been difficult in contemporary times ${ }^{380}$ because of Supreme Court decisions stripping tribal courts of jurisdiction over crimes committed by non-Indians ${ }^{381}$ and federal statutes diminishing tribal sentencing authority. ${ }^{382}$ And while the federal

113-14 (2010) (describing increasing documentation of domestic violence against Cherokee women in the 1800s).

373. See, e.g., JOHNSTON, supra note 365, at 77, 113, 122.

374. See PERDUE, supra note 363, at 152-53.

375. See generally VIRGINIA MOORE CARNEY, EASTERN BAND CHEROKEE WOMEN: CULTURAL PERSISTENCE IN THEIR LETTERS AND SPEECHES (2005) (examining the theme of cultural persistence manifested in Eastern Cherokee women's own speeches and letters dating back to the 1700s, including during key encounters with European and American society).

376. See PERDUE, supra note 363, at 146-47.

377. See, e.g., JoHnSTON, supra note 365, at 77, 113-14, 122-23. For another view pertaining to the experiences of Cherokee women in Oklahoma, see RosE STREMLAU, SUSTAINING THE CHEROKEE FAMILY: KINSHIP AND THE ALLOTMENT OF AN INDIGENOUS NATION (2011) (arguing that in the 1900s Oklahoma Cherokee families' organization, cultural values, and social and economic practices allowed them to adapt to private land ownership by incorporating elements of the new system into existing domestic and community-based economies).

378. LAURENCE French \& Jim HORnBUCKLE, THE CHEROKEE PERSPECTIVE: WritTEN BY EASTERN CHEROKEES 108-12 (1981).

379. See id. at 123-44; see also STOP Violence Against Native Women, SOVEREIGN STATE OF THE KENAITZE, http://www.kenaitze.org/index.php/2012-07-08-11-05-53/stop-violence-against -native-women (last visited Nov. 6, 2013) (stating that “domestic violence is not a tribal tradition”).

380. See, e.g., Rebecca A. Hart \& M. Alexander Lowther, Honoring Sovereignty: Aiding Tribal Efforts to Protect Native American Women from Domestic Violence, 96 CALIF. L. REV. 185, 226-28 (2008) (proposing Congressional changes to the Oliphant rule and ICRA to address the problem of domestic violence in Indian Country); Jasmine Owens, "Historic" in a Bad Way: How The Tribal Law and Order Act Continues the American Tradition of Providing Inadequate Protection to American Indian and Alaska Native Rape Victims, 102 J. CRIM. L. \& CRIMINOLOGY 497, 521 (2012).

381. See Oliphant v. Suquamish, 435 U.S. 191 (1978).

382. For a thorough discussion of congressional limits on tribal criminal punishing authority via the Indian Civil Rights Act and Public Law 280, see Carole Goldberg \& Duane Champagne, 
government has law enforcement authority over violent crimes occurring on reservations, it has a record of declining to exercise this power, creating an enforcement gap. ${ }^{383}$

It is against this backdrop of escalating rates of sexual assault and domestic violence against women that the Special Rapporteur made her 2011 visit to Eastern Cherokee. One of her first meetings included instruction about the traditional legal and social system of the Cherokees. ${ }^{384}$ Terri Henry, a Councilwoman in the Eastern Band, explicated the link between United States Indian policy and contemporary violence in Native communities. She invoked the federally ordered relocation of the Cherokees to Indian Country in 1838 via the "Trail of Tears" to emphasize that the "Removal Act legalized the deaths of thousands of Cherokee., ${ }^{385}$ Indeed, the Eastern Band of Cherokees are direct descendants of those who tried to resist the relocation and whose descendants ultimately rebuilt their society amid the states and citizens that had sought to expel them. ${ }^{386}$ Henry explained that the history reveals a legacy of violence and oppression that lives on in the disparate treatment of Indians in the United States. ${ }^{387}$

By the time of the Special Rapporteur's visit, women within the Eastern Band of Cherokees had for years been trying to address issues of social justice and cultural revitalization in their community. ${ }^{388}$ With respect to violence against women, several women formed Clan Star Inc. to pursue advocacy through tribal, federal, and international channels to end violence within the community by promoting traditional tribal values of respect for all living things

Searching for an Exit: The Indian Civil Rights Act and Public Law 280, in THE INDIAN CIVIL RIGHTS ACT AT FORTY, supra note 18, at 247, 249-54.

383. See Kevin K. Washburn, Federal Criminal Law and Tribal Self-Determination, 84 N.C. L. REv. 779, 818 \& n.25 (2006). For a thorough discussion of the federal criminal justice system in Indian Country, see Kevin K. Washburn, American Indians, Crime and the Law: Five Years of Scholarship on Criminal Justice in Indian Country, 40 ARIZ. ST. L.J. 1003 (2008); Kevin K. Washburn, American Indians, Crime, and the Law, 104 MiCH. L. REV. 709 (2006). See also Troy A. Eid \& Carrie Covington Doyle, Separate but Unequal: The Federal Criminal Justice System in Indian Country, 81 U. CoLO. L. REV. 1067, 1099-1100 (2010) (arguing that the Major Crimes Act of 1885 is unconstitutional as applied to Indians in Indian Country today).

384. See UN Expert to Visit Cherokee, North Carolina to Study the Epidemic of Violence Against Native Women, INDIAN LAW RESOURCE CENTER (Jan. 21, 2011), http://www.indianlaw.org /content/un-expert-visit-cherokee-north-carolina-study-epidemic-violence-against-native-women.

385. See Terri Henry, Restoring Respect for the First Women of This Land, INDIAN LAW RESOURCE CENTER (Feb. 2, 2011), http://www.indianlaw.org/safewomen/restoring-respect-first -women-land.

386. See Barbara R. Duncan, Introduction to Living STORIES OF THE CHEROKEe 1, 7-8 (Barbara R. Duncan ed., 1998) (recounting the story of the Cherokee man "Tsali" who resisted relocation and then submitted himself for execution (along with his sons) in exchange for the United States' promise to stop persecuting the Cherokee remaining in the east).

387. Henry, supra note 385.

388. See, e.g., CARNEY, supra note 375, at 163-74 (arguing that Cherokee women have had a powerful role in sustaining their culture and community, through generations of advocacy on myriad issues). 
and honoring women. ${ }^{389}$ As Clan Star's mission statement asserts: “any abuse is not traditional and is not acceptable.”390 Clan Star advocated for national legislation including the Violence Against Women Act of 2005 and participated in briefing the Jessica Gonzales case before the Inter-American Court on Human Rights. ${ }^{391}$

Tribal government too has addressed violence against women at Eastern Cherokee. In 2002, the Eastern Band enacted a statute on domestic violence, which provides avenues to the tribal courts for redress and protections. ${ }^{392}$ Forms of relief include final protective orders and temporary ex parte orders in emergency situations to aid and support victims in numerous respects. ${ }^{393}$ The Eastern Band has also enacted enhanced emergency responder, public safety, judicial, and offender rehabilitation programs. In addition, the tribe has been involved in advocacy at the national level, supporting the 2010 Tribal Law and Order Act's (TLOA) enhancement of tribal court sentencing authority. Tribal leadership also supported the Violence Against Women Act's provisions for concurrent tribal court jurisdiction over certain domestic violence crimes committed by non-Indians. ${ }^{394}$ In 2012, the Eastern Band Tribal Court, acting on its expanded authority under the TLOA, handed down a four-year sentence for a domestic violence conviction, one of the longest sentences ever imposed by the court. ${ }^{395}$ Today "Cherokee women have the right as citizens of the Eastern Band to the protection of their government." 396

As Councilwoman Henry explained, the visit of Special Rapporteur Manjoo in 2011 gave the Eastern Band an opportunity to showcase tribal

389. About CSI, CLAN STAR INC., http://www.clanstar.org/about-csi (last visited Nov. 10, 2013).

390. Id.

391. See id. Clan Star, Inc. was one of a group of "non-profit organizations and tribal governments actively working to end the epidemic of violence against American Indian and Alaska Native women" who participated as amici in the Jessica Gonzales case, joining a brief authored by attorneys at the Indian Law Resource Center. See Brief for Indian Law Resource Center et al. as Amici Curiae Supporting Plaintiff, Gonzales v. United States, Case 1490-05, Inter-Am. Comm'n H.R., Report No. 52/07, OEA/Ser.L/V/II.130 Doc. 22, rev. 1 (2007), available at http://indianlaw.org /sites/default/files/resources/final\%20with\%20sign\%20ons_12Nov08_amicus\%20brief\%20gonzales\% 20v.\%20US.pdf. See generally Caroline Bettinger-López, Human Rights at Home: Domestic Violence as a Human Rights Violation, 40 COLUM. HUM. RTS. L. REV. 19 (2008) (discussing the Jessica Gonzales case).

392. See CHEROKEe CODE, ch. 50B (2010), available at http://www.narf.org/nill/Codes /ebcicode/50bviolence.pdf.

393. Id. § 50B-7.

394. The Violence Against Women Act was reauthorized in February 2013 and contained provisions providing for tribal jurisdiction over the investigation, prosecution, and sentencing of Indian and non-Indian perpetrators of domestic violence against an Indian partner or spouse in Indian country. Violence Against Women Reauthorization Act of 2013, Pub. L. No. 113-4, § 904, 127 Stat. 54, 120 23.

395. See Tribal Court Issues Four Year Sentence on the Heels of Tribal Law and Order Act, CHEROKEE ONE FEATHER (Apr. 18, 2013), http://theonefeather.com/2013/04/tribal-court-issues-four -year-sentence-on-heels-of-tribal-law-and-order-act.

396. Henry, supra note 385. 
lawmaking and programmatic responses to the domestic violence crisis, and the change in consciousness that the community has experienced about these issues. As Henry said, “Ms. Manjoo’s visit provided the setting for our community to talk openly about our desire to ensure that women can live lives free from violence.” ${ }^{397}$ The Eastern Band revealed that the tribal response to domestic violence is a holistic and collective process wherein all women and all families affected by domestic abuse "must be healed," not only "by the immediate intervention of law enforcement [and] prosecution," but also by "education, counseling, and other appropriate services." 398 More broadly, as Henry says, "legal reform often takes years, even decades."399 Thus, addressing violence against women involves not only increasing the law enforcement powers of tribal government, but also of getting together "as tribal relatives" to "find additional ways to protect women and deal with the monsters amongst us." 400

In many respects, the Eastern Band's response to violence against women is a jurisgenerative moment in indigenous rights. While Cherokee women had long advocated for reform through tribal and national law, their engagement with the Inter-American Commission and Special Rapporteur has connected the experience of Cherokee women with all women across the globe who seek justice under the law and a life free of violence. At the same time, as the Special Rapporteur's Report becomes an aspect of the international human rights discourse on violence against women, that movement and conversation can begin to reflect the particular experiences, histories, and values of indigenous women. The Special Rapporteur noted the many ways the history and legacy of colonization contribute to the indigenous domestic violence problem - and stressed the role of indigenous communities in developing contemporary solutions, both tribal and national, to domestic violence. ${ }^{401}$ These are potentially transformative departures from the narrow focus on individuals and states, ${ }^{402}$ and indigenous versus Western solutions, ${ }^{403}$ that sometimes

397. Id.

398. CHEROKEE CODE, ch. 50B, § 50B-1 (2010), available at http://www.narf.org/nill/Codes /ebcicode/50bviolence.pdf. Scholars have noted that measures to address domestic violence must address the broader impacts of colonization on indigenous and aboriginal women. See Rashmi Goel, No Women at the Center: The Use of the Canadian Sentencing Circle in Domestic Violence Cases, 15 WIS. WOMEN's L.J. 293, 331 (2000) (arguing that "[i]f sentencing circles are to be effective in combating domestic violence and meeting the needs of Aboriginal victims," they must be used handin-hand with measures to restore women to their "honored place" in Aboriginal society through "education about the role and status of women in traditional Aboriginal society, specific measures to restore the traditional role of Aboriginal women in tribal government, spiritual events and rituals, and within the family").

399. Henry, supra note 385.

400. Id.

401. See Report of Special Rapporteur Manjoo, supra note 357.

402. For a sampling of the vast literature considering, often critically, the role of the state in responding to domestic violence matters, see, e.g., Deborah Epstein, Procedural Justice: Tempering the State's Response to Domestic Violence, 43 WM. \& MARY L. REV. 1843, 1849-56 \& n.45 (2002) 
characterizes the discourse about American Indian women and domestic violence. This is one example of the jurisgenerative process at work, suggesting the capacity of indigenous and international human rights norms to influence one another toward individual and collective well-being.

\section{CONCLUSION}

A recent report of the International Law Association Committee suggested that state and international practices supportive of indigenous rights have "progressively increase[ed] over the last few decades like a flooding river under an unstoppable rain." ${ }^{404}$ In this regard, the indigenous human rights movement, with its historic antecedents and contemporary advancements, is unfolding before our eyes. With certain key instruments in place, today the challenge is to strengthen and implement indigenous rights in nations around the globe. ${ }^{405}$

While it is too early to make conclusive judgments about the ultimate trajectory or effect of the indigenous rights movement, several aspects are already apparent. This is a story about disparate groups who, having a shared, common history of devastation by European conquest and domination, have come together as a global community of indigenous peoples determined to make human rights make a difference. It is a story of indigenous agency and indigenous values, resilient over time and ascendant in the twenty-first century. It is a story of the development and implementation of human rights law that is occurring, and must occur, formally and informally, through dynamic and interrelated actions in international, domestic, and tribal venues alike. Bolstered by postwar exigencies and subsequent global commitments to human rights, indigenous peoples are finally able to embrace the shared, global vision of human rights on their own terms.

And, finally, this is a story of peoples who never expected human rights to be pure or romantic. With their eyes wide open, indigenous peoples are using

(tracing the evolution of response to domestic violence from the private to public realm and describing some scholars' opposition to the one-size-fits-all quality of law enforcement interventions that fail to account for context of women's lives); Jenny Rivera, The Violence Against Women Act and the Construction of Multiple Consciousness in the Civil Rights and Feminist Movements, 4 J.L. \& POL'Y 463, 506 (1996) ("Dependence on initiatives which are strategies for authorizing state involvement in individual relationships have proved debilitating for communities of color and women.”); Jeannie Suk, Criminal Law Comes Home, 116 YALE L.J. 2, 5-11 (2006) (arguing that the criminalization of domestic violence enables state intrusions on the home and intimate relationships, with disproportionate impacts on minorities, in ways that merit exploration).

403. Compare Robert Yazzie, "Life Comes from It": Navajo Justice Concepts, in NAVAJO Nation Peacemaking: Living Traditional Justice 4 (Marianne O. Nielsen \& James W. Zion eds., 2005) (describing Navajo conceptions of justice and associated peacemaking), with Donna Coker, Enhancing Autonomy for Battered Women: Lessons from Navajo Peacemaking, 47 UCLA L. REV. 1 (1999) (cautiously examining the use of peacemaking in Navajo domestic violence cases and recommending an individual "autonomy enhancing” approach).

404. See MORGAN, supra note 212, at 149 (internal quotations omitted).

405. See generally ECHO-HAWK, supra note 3. 
human rights law, infused with indigenous norms and processes, as an empowering tool in their struggle for decolonization and cultural survival, in relationship with the land and with others who inhabit it. ${ }^{406}$ This is, in our view, a jurisgenerative moment in indigenous rights - a moment when human rights have the potential to become more capacious, embracing norms of equality and self-determination, and multiple means of implementation, to reflect the ways that individuals and peoples around the globe live, and want to live, today.

406. See Samuel Moyn, Human Rights, Not So Pure Anymore, N.Y. TIMES, May 12, 2012, at SR5 ("[T]he main difference between then [the 1970s] and now is that the whole idea of human rights has lost some of its romantic appeal and moral purity.”). 